Robert M. Conroy

University of Virginia

Robert S. Harris

University of Virginia

Young S. Park

Rikkyo University

\title{
Analysts' Earnings Forecast Accuracy in Japan and the United States
}

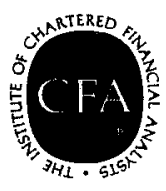

The Research Foundation of

The Institute of Chartered Financial Analysts 


\section{Analysts' Earnings Forecast Accuracy in Japan and the United States}


(C) 1994 The Research Foundation of the Institute of Chartered Financial Analysts

All rights reserved. No part of this publication may be reproduced, stored in a retrieval system, or transmitted, in any form or by any means, electronic, mechanical, photocopying, recording, or otherwise, without the prior written permission of the copyright holder.

This publication is designed to provide accurate and authoritative information in regard to the subject matter covered. It is sold with the understanding that the publisher is not engaged in rendering legal, accounting, or other professional service. If legal advice or other expert assistance is required, the services of a competent professional should be sought.

ISBN 10-digit: 0-943205-27-1 ISBN 13-digit: 978-0-943205-27-4

Printed in the United States of America

August 1994 


\section{Mission}

The mission of the Research Foundation is to identify, fund, and publish research material that:

- expands the body of relevant and useful knowledge available to practitioners;

- assists practitioners in understanding and applying this knowledge; and

- enhances the investment management community's effectiveness in serving clients.

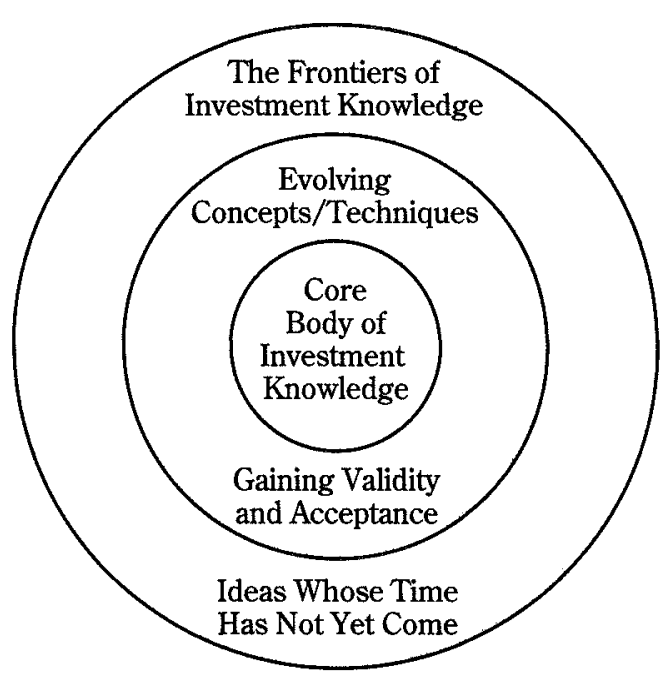

The Research Foundation of

The Institute of Chartered Financial Analysts

P.O. Box 3668

Charlottesville, Virginia 22903

U.S.A.

Telephone: $804 / 977-6600$

Fax: 804/977-1103 


\section{Acknowledgments}

Completion of this work involved the support and encouragement of many. We thank the Research Foundation of the ICFA for its support of the project. We thank Citicorp, especially Peter Thorpe, for support under its Citibank/Darden Global Scholars program. Both Darden authors thank Darden Sponsors for financial support and the School's general support for research that crosses national boundaries. We thank Morgan Stanley and IBES, Inc., for supplying data that made the research possible. Some of the work was completed while Conroy was a visitor at International University of Japan, and we appreciate that institution's support. Thanks also go to Zhenhui Xu and Michael Ho for excellent research assistance, Lee Sellman for invaluable help in manuscript preparation and friends and colleagues for their insights, including Mark Haskins, Darwin Bayston, and Rick Boebel. Lastly, we thank those who were kind enough to meet with us in Japan and help broaden our understanding of the role of analysts there, including:

Toru Fukuda

Daiwa Institute of Research, Inc.

Teruyoshi Gotoh

Daiwa International Capital Management

Hiroshi Ishikawa

Wako Research Institute of

Economics, Inc.

Naoko Mori

The Security Analysts Association of Japan

Sakae Murakami

Wako Research Institute of Economics, Inc.

Kazuhiko Nagami

Okasan Economic Research Institute

Hiroshi Nakagawa

Morgan Stanley Japan Ltd.
Taiichiro Ogawa

The Security Analysts Association of Japan

Kazuo Ohmura

M \& K Co., Ltd.

Randal Pearson

IBES, Inc.

Fumiyoshi Sakai

Yamaichi Research Institute of Securities \& Economics, Inc.

Yukio Tada

Nissho Iwai Corporation

Akitoshi Takatsuki

The Sakura Bank, Limited

Ken'ichiro Yoshida

The Nikko Research Center, Ltd.

Robert M. Conroy Robert S. Harris

Young S. Park 


\section{Foreword}

Possibly the greatest recent phenomenon in securities investing is the substantial expansion in the ownership of non-U.S. assets. No longer are investors content to confine their portfolios to U.S. securities. The resulting dramatic movement to global portfolios is predicted to continue on into the 21 st century. Nowhere has securities growth been more prominent than in Japan. Although considered to be an "emerging market" as recently as the early 1960s, Japan now ranks second worldwide in stock market capitalization.

Institutional settings and practices differ considerably across national boundaries. Such differences are especially noticeable between the world's two largest equity markets, Japan and the United States. The astute global investor must be aware of and responsive to these differences. In this paper, Professors Robert M. Conroy, Robert S. Harris, and Young S. Park provide a comprehensive comparison of the properties of financial analysts' earnings forecasts in Japan and the United States. Their paper provides an in-depth look at the differences in institutional practices with respect to earnings and earnings forecasts, as well as a thorough empirical comparison of earnings forecast accuracy in the two markets.

Although some controversy remains about the accounting conventions used to compute earnings for Japanese companies, the authors conclude that earnings play an important role in the Japanese equity markets. In arriving at their conclusion, they carefully examine key issues such as corporate disclosure of earnings, accounting conventions, and share cross-holdings in Japan.

A substantial volume of research exists on earnings, earnings forecasts, and stock prices in the United States, but there is a paucity of such research on the Japanese market. Thus, a major contribution of the Conroy, Harris, and Park research is the measurement of earnings forecast accuracy and the effect of earnings on share prices in Japan. The authors compare earnings forecast accuracy from 1985 to 1992 for samples of companies drawn from the Tokyo Stock Exchange and the New York Stock Exchange. Their empirical investigation provides interesting, and sometimes surprising, results. Most prominent among their findings is that analysts' earnings forecasts in Japan have been consistently more accurate than forecasts in the United States.

The authors suggest several reasons for the greater accuracy in Japanese earnings forecasts. Foremost among these reasons is the fact that Japanese analysts face an easier forecasting challenge because Japanese earnings exhibit less variability than U.S. earnings. A particularly interesting reason for 
the forecast accuracy differences is that Japanese analysts were not as overoptimistic as their U.S. counterparts. This difference may be attributable to the fact that the Japanese earnings predictions came from a non-sell-side source (Toyo Keizai), whereas the U.S. forecasts came from sources engaged in making recommendations for stock selection (the Institutional Brokers Estimate System).

The contributions this monograph makes cannot be overestimated. Important differences exist in benchmarks for earnings forecasts between Japan and the United States. An understanding of such differences is paramount to the success of investments in the Japanese equity markets. Conroy, Harris, and Park explain how to understand and interpret the effect of earnings and earnings forecasts on Japanese stocks.

The Research Foundation is pleased to sponsor this important work, which sheds new light on an important, yet often misunderstood, topic. Practicing investment managers should reap benefits from this work for many years to come.

John W. Peavy III, CFA Board of Trustees The Research Foundation of The Institute of Chartered Financial Analysts 


\section{Earnings Forecast Accuracy in Japan and the United States}

In 1985, U.S. investors had $\$ 120$ billion of foreign securities in their portfolios. Analysts project this figure to increase seven-fold by the year 2000 as international diversification continues. With the growth in investment across national boundaries, knowledge of institutional settings and practices in other countries becomes increasingly important for sound equity selection. In this study, we provide a comprehensive comparison of the properties of financial analysts' earnings forecasts in the world's two largest equity markets, Japan and the United States.

In the United States, forecasts of corporate performance consume considerable resources and play a key role in financial markets' valuation of companies. Although the popular press often discounts the role of earnings in Japanese markets, recent works (Elton and Gruber 1989; Conroy, Harris, and Park 1993b) show that Tokyo Stock Exchange prices react strongly to earnings information, especially analysts' forecasts. As a result, understanding such forecasts can be an important tool for investment analysis and understanding of Japanese markets.

Our work compares “industry benchmarks" for earnings forecasts in Japan and the United States. These benchmarks are forecasts against which an individual analyst's forecasts are typically gauged. Moreover, deviations of actuals from these benchmarks are often interpreted as surprises to the market that drive revaluation of equity prices. Our main conclusions are summarized below.

- Corporate earnings and earnings forecasts are important for the pricing of stocks in Japan, as an increasing body of research demonstrates. The role of such fundamental information is crucial to understanding Japanese markets.

- Important institutional differences exist between the two countries in the calculation, reporting, and disclosure of information on corporate performance. The Japanese industry standard forecasts that we studied were made by Toyo Keizai. Toyo Keizai is primarily an information provider, not a securities firm making stock recommendations. It also has access to management 
information that typically would not be available to U.S. analysts. U.S. industry standards, such as the Institutional Brokers Estimate System (IBES) and Zacks, are collections of forecasts from private (typically sell-side) analysts.

- During the 1985-92 study period, analysts' earnings forecasts in Japan (made by Toyo Keizai) were consistently more accurate than forecasts in the United States (as measured by IBES). This superior accuracy holds for forecasts of the year about to end, as well as for the next fiscal year. The better accuracy in Japan is to a considerable measure driven by avoidance of large forecast errors found for some U.S. companies.

- The difference in forecast accuracy between the United States and Japan cannot be ascribed to differences in industrial composition of the two equity markets. Even though industries do make a difference, Japanese forecasts were more accurate than U.S. forecasts in each industry studied.

- One explanation of the superior forecast accuracy in Japan is that Japanese analysts face an easier forecasting challenge. Our results show that a simple no-change (random walk) forecast in Japan is more accurate than the same type of forecast in the United States. In addition, we found that negative earnings have been less prevalent among Japanese companies than among U.S. companies. Negative earnings are a major source of forecast error because analysts seldom forecast downturns. As a result, differences in forecasting challenge go a long way toward explaining the different forecast accuracy in the two countries. Even when companies with negative earnings were eliminated, however, U.S. forecasts were less accurate than those in Japan.

- Japanese analysts (Toyo Keizai) did not exhibit the overoptimism found in U.S. IBES forecasts. This relative absence of rose-colored glasses in Japan may reflect the predictions of an information provider that is not engaged in making recommendations for stock selection. In contrast, IBES forecasts in the United States come from sell-side analysts.

- Toyo Keizai forecasts have been more accurate and less optimistic than the relatively new IBES data in Japan. These forecast differences suggest that differences between an information provider and sell-side analysts in IBES may play an important role in understanding published forecasts. Some evidence indicates, however, that this differential is disappearing and that, in part, it may reflect stale forecasts contained in the IBES data.

\section{Earnings Forecasts in Japan}

Before describing the empirical analysis, we provide a brief overview of institutional features surrounding earnings and earnings forecasts in Japan. Appreciation of substantial differences between the United States and Japan is a key ingredient to understanding the formation and role of analysts' forecasts 
in Japan. As a backdrop for the forecasts themselves, we describe the legal and financial market practices surrounding earnings disclosure. We then touch on key accounting issues that make any direct comparison of U.S. and Japanese earnings problematic. Next, we discuss briefly the share cross-holdings among Japanese firms, because they play a prominent role in the link between levels of corporate earnings and share prices. With this institutional detail in place, we discuss specific earnings forecasts available in Japan.

Corporate Disclosure of Earnings in Japan. Legal and stock exchange policies both affect the type and timing of earnings information Japanese companies release. The net result is that, historically, Japanese investors have relied on unconsolidated "parent-only" earnings. Most exchange-listed companies announce these unconsolidated earnings figures, as well as management forecasts of next year's earnings, within two months of the ends of their fiscal years.

Japan's Commercial Code requires companies to prepare unconsolidated annual reports and distribute them within three months of the fiscal year end. Because most Japanese firms have a fiscal year ending on March 31, the code's effect is to make most annual reports due by the end of June. Appendix A provides a distribution of fiscal years in the United States and Japan.

The Japanese Securities and Exchange Act, which covers companies listed on the Japanese exchanges, has further reporting demands and requires firms to prepare three kinds of financial statements: unconsolidated annual reports, unconsolidated semiannual reports, and consolidated annual reports. ${ }^{1}$ These must be filed with the Ministry of Finance within three months of the fiscal year's end. Until 1988, the law permitted the consolidated reports to be filed later, typically within four months of the fiscal year's end. In almost all cases, the unconsolidated, or "parent-only," report is filed before the consolidated report. ${ }^{2}$ Most of the attention in Japan has been on the parent-only information, in large part because it is released first. Also, prior to 1978, consolidated figures were not reported at all.

\footnotetext{
${ }^{1}$ The United States is atypical in requiring quarterly reports. Most of the rest of the globe requires only annual or semiannual statements.

${ }^{2}$ Typically, unconsolidated numbers become public by the middle of May and consolidated numbers become public about 50 days later. For an analysis of the difference in timing between unconsolidated and consolidated announcements, see Ito (1990). During the period of this study, 1985 through 1992, unconsolidated (parent-only) data were reported first; in 1992, however, the timing gap between the unconsolidated and consolidated statements began to decrease and will ultimately be eliminated.
} 
In addition to the legal requirements, Japanese exchanges request that a firm publicize condensed financial statements immediately upon board of director approval of draft financial statements. As a result, most earnings announcements effectively take place well before the three-month legal deadline. For instance, for the vast majority of Japanese companies, earnings figures are public within 40 trading days of the end of the fiscal year (see Conroy, Harris, and Park 1993b). A major difference between the United States and Japan is that Japanese exchanges request companies to publicize forecasts of next year's earnings. As a consequence, management forecasts are announced simultaneously with actual earnings.

The process of publicizing financial results begins with an announcement to analysts at the Tokyo Stock Exchange (TSE) and a two- or three-page summary placed in mailboxes of Tokyo Press Club members. These results are picked up almost immediately by on-line services such as Nikkei Quick (a subsidiary of the Nihon Keizai Shinbun, the major business newspaper in Japan and the counterpart of the Wall Street Journal in the United States). The following day's Nihon Keizai Shinbun will report the following items from the condensed financial statement: net sales, ordinary income, net income, earnings per share, and proposed dividends per share. In total, the newspaper reports three years of data. For example, in 1989, the paper reported actual results for 1988 and 1989 and the company forecast for 1990.

Typically, this series of public announcements is not preceded by analyst briefings, so it represents a concentrated two-day period in which new information becomes public. In interviews with financial analysts at all of the major security firms in Tokyo, we found that some firms will schedule analyst briefings the day they issue their three-page summaries. More typically, firms schedule such briefings within the following two weeks. In addition to the general analyst briefing, most analysts already will have scheduled their own private meetings with management to take place shortly after the firm's public announcement of earnings.

Most companies have only minimal contact with financial analysts between the end of the fiscal year and the release of the condensed financial statements. Firms generally refrain from making any financial announcements prior to board approval of the draft of condensed financial statements. The one exception to this relative silence involves a Ministry of Finance rule that, since 1989, requires firms to publicize substantial changes in their financial performance. The standard is a 30 percent change in earnings from those previously expected by management. Thus, for large earnings changes, the release of the condensed financial statement may be preceded by a public disclosure of information in the upcoming release. 
Accounting lssues. Afrequent concern in comparing earnings across national boundaries centers on differences in accounting standards. Choi and Levich (1991) reported that half of the respondents to their survey of institutional investors, corporate issuers, investment underwriters, and market regulators felt that international accounting differences influenced their capital market decisions. For the present study, such differences do not play as large a role as in many other studies, because the focus here is on forecast accuracy not the level of earnings per se. Nonetheless, an appreciation of some of the major differences between accounting practices in Japan and the United States is essential in understanding the role of earnings figures in Japan. Table 1 highlights some of the differences between U.S. and Japanese accounting practices. Here, the focus will be on three key issues: consolidation of subsidiary earnings, depreciation reporting, and certain other rules such as treatment of special reserves. ${ }^{3}$

- Earnings consolidation. In the United States, consolidated earnings are the primary measure of earnings. These include the net income of subsidiaries and firms in which the parent holds 20 percent of the outstanding shares. In Japan, consolidation has historically never had as large a role. Tax authorities have not allowed such consolidation for figuring tax obligations, some companies have not reported consolidated figures, and consolidated figures often have come out long after unconsolidated results. ${ }^{4}$ Zielinski and Holloway (1991, p. 135) note that "because consolidation standards are so fluid and disclosure so poor ... investors have tended to ignore" consolidated figures.

A firm can leave both profits and losses in unconsolidated subsidiaries. Although consolidation can sometimes lead to increased (and highly publicized) profits for keirets $u$ leaders, such as Toyota and Hitachi, it may depress profits for some companies and have a negligible effect on others. Mattione (1992) analyzed all nonfinancial firms on the first section of the TSE and concluded that consolidation would have increased earnings in 1990 by 13 percent. After adjusting for double counting of earnings attributable to crossholdings, however, Mattione noted that such consolidated earnings would only be 8.4 percent above parent-only earnings in 1990 . Zielinski and Holloway (1991) estimated that, for the same year, consolidation would reduce reported price-earnings ratios $(\mathrm{P} / \mathrm{Es})$ of Japanese-traded shares by less than 8 percent on average.

Going forward, as standards become more uniform and the information

\footnotetext{
${ }^{3}$ See Bavishi and Bepler (1990) and Choi and Levich (1991) for a discussion of how some investors cope with international accounting diversity.

${ }^{4}$ See Mattione (1992) for a discussion of consolidation principles in Japan.
} 


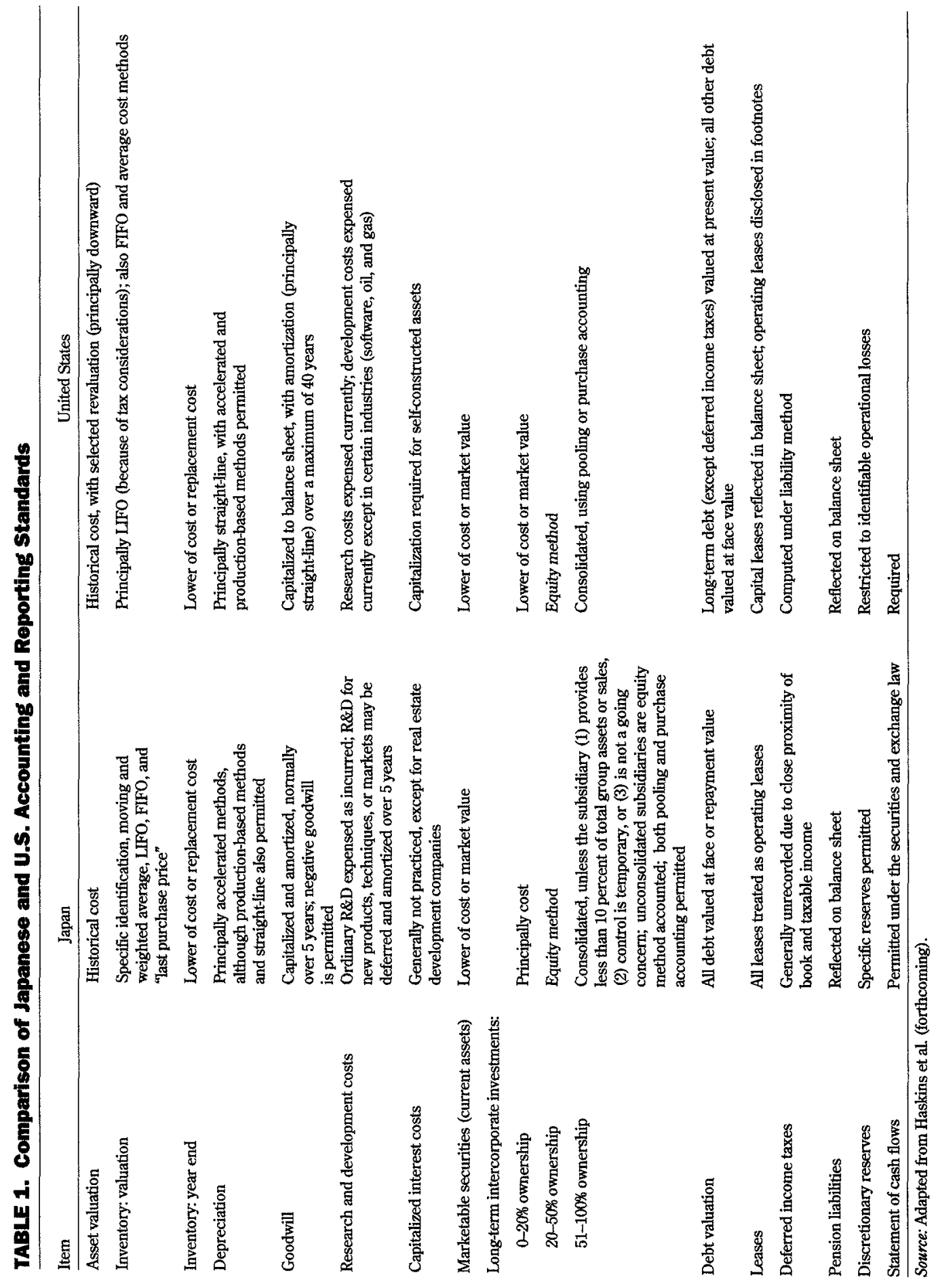


more timely, consolidated figures will likely play a larger role in Japanese markets. As of 1993, however, the Japanese analysts we interviewed continued to stress the primary role of parent-only numbers, and published $\mathrm{P} / \mathrm{Es}$ are typically based on unconsolidated figures. Given the current and past investor attention to parent-only figures, our analysis will focus on unconsolidated earnings numbers.

- Depreciation. Unlike in the United States, depreciation is reported in Japan on an accelerated basis both to tax authorities and to the public. Given a growing series of capital expenditures, this practice makes Japanese reported earnings lower than would be the case under the U.S. tax treatment. ${ }^{5}$ As an example, 1990 depreciation expenses exceeded 1.5 percent of after-tax earnings in Japan; the comparable figure in the United States was about 1 percent. This bias would eventually reverse itself if capital expenditures were to fall. Although such a difference in depreciation standards affects some comparisons across countries (e.g., P/Es), it should not have a major impact on predicting earnings within a particular country.

- Other rules. In addition to consolidation and depreciation, some other specific accounting differences may take on material importance. For instance, Japanese firms have the ability to create reserves that can be used to reduce reported earnings. Charges to such reserves can be especially important for large insurance companies. Japanese rules also have allowed companies to flow-through certain items (e.g., gains on financial transactions) to recurring income that would be extraordinary gains in the United States. The overall effect is that Japanese managers apparently have more degrees of freedom in reporting than do their U.S. counterparts. Such liberties may result in smoothing or other manipulation of earnings that would allow a firm to attain its earnings projections.

Share Cross-Holdings in Japan. Figure 1 shows that corporate entities own as much as three-quarters of the value of exchange-listed shares in Japan. Many of these holdings are part of complex corporate relationships such as keiretsu. ${ }^{6}$ In addition to their implications for corporate behavior, such cross-holdings affect the interpretation of reported figures on earnings and

\footnotetext{
${ }^{5}$ Mattione (1992) argues that, in comparison with true economic depreciation, the Japanese depreciation methods do not bias their reported earnings by more than the bias in the United States. This opinion is based on observing the fast pace of business investment in Japan, coupled with a more capital-intensive production process.
}

${ }^{6}$ For a discussion of the nature of the Japanese firm, see Aoki (1990). 
FIGURE 1. Ownership of Listed Equities in Japan

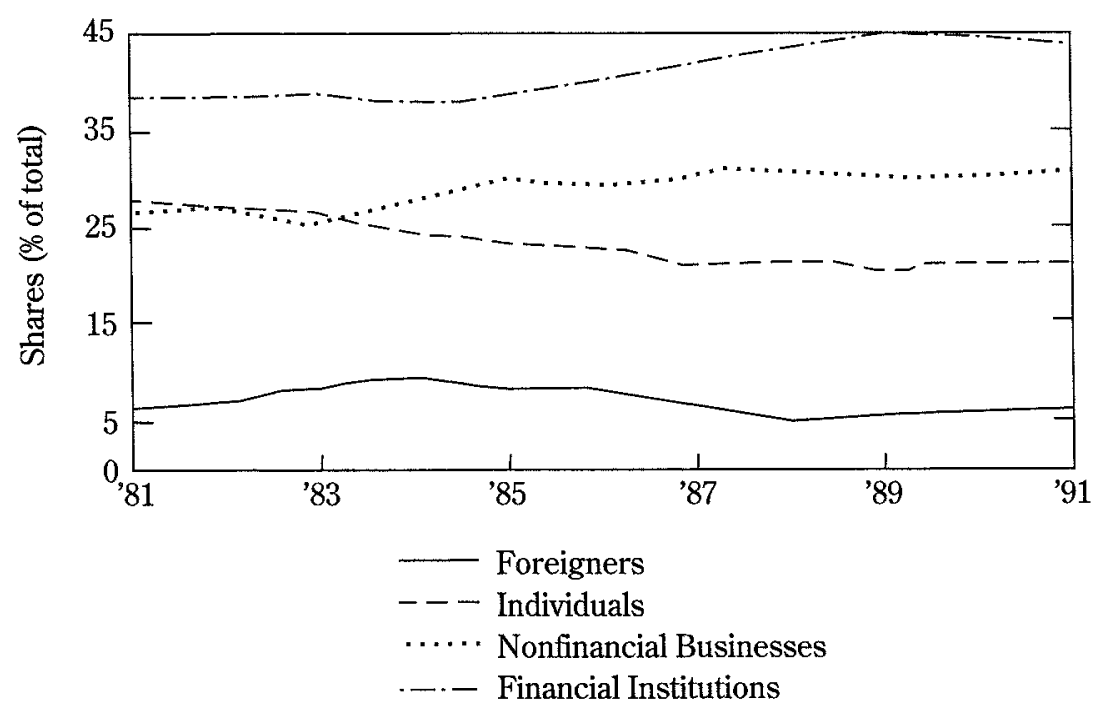

Source: Mattione, 1992.

share values. Cross-holdings affect earnings because dividends received are counted as earnings; the impact is mitigated, however, by the relatively low dividend payout ratios and dividend yields in Japan. For instance, during the $1980 \mathrm{~s}$, the average dividend yield in Japan was 1.0 percent compared with 4.3 percent in the United States and 4.7 percent in the United Kingdom (Japan Securities Research Institute 1992).

Cross-holdings have a substantial role in determining market value. Estimates of the value of cross-holdings as a percent of the market value of listed shares in Japan were in the range of 52-60 percent during the past decade (Mattione 1992). As a result, unadjusted market values overstate the true value of the operations and underlying assets of Japanese-listed companies. The net effect is that reported $\mathrm{P} / \mathrm{Es}$ are overstated because of cross-holdings (not to mention the accounting issues cited earlier). Many people have attempted to restate Japanese $\mathrm{P} /$ Es to put them on a footing comparable with other markets. Table 2 shows that the adjustments for cross-holdings can be substantial, but they alone are not enough to explain the extremely high Japanese P/Es of the late 1980s.

The presence of cross-holdings complicates the prediction of earnings to the extent that dividends received from shares will flow into earnings. In addition, cross-holding introduces a link between the earnings of two compa- 
TABLE 2. Price-Earnings Ratios Adjusted for Share Cross-holdings

Effects of share cross-holdings

$\mathrm{P} / \mathrm{E}$ reported

Cross-holdings (\%)

Adjusted P/E

Actual reported $P / E s$

Japan

United States

United Kingdom

West Germany

France
Early 1980 s

18

52

10.3

$\underline{1980}$

20.4

7.9

6.8

8.1

7.5 $\underline{1989}$

70

60

33.7

$\underline{1989}$

70.6

11.7

11.3

15.6

12.3

Sources: Cross-holdings data adapted from Mattione (1992). Reported P/Es from Japan Securities Market Research Institute (1992), p. 55. Japanese figures are for first section of the Tokyo Stock Exchange.

nies, because the earnings of one will depend on the earnings of the other (via dividends received on shares held). Finally, strong corporate links accompanying cross-holdings may stabilize the profitability of at least some companies. For instance, a supplier to another corporation may have little uncertainty about the demand for its product.

Sources of Analysts' Earnings Forecasts in Japan. In the United States, early research relied on earnings forecasts made by a particular firm such as Value Line or Standard \& Poor's. Recently, researchers and market participants have turned to broad-based compilations of individual forecasts, such as IBES, Zacks, and FirstCall, as sources of information. For our analysis of U.S. companies, we use IBES data, which contain a compilation of earnings per share (EPS) estimates from individual (sell-side) financial analysts. We use mean forecasts (averages across individual analysts) of EPS for the current fiscal year and the subsequent fiscal year. Practitioners use these mean forecasts as a gauge of market expectations, and research has shown them to be important in determining share prices (see, for example, Elton, Gruber, and Gultekin 1981; Brown 1993). IBES compiles an annotated bibliography of research using IBES forecasts, which exceeded 280 entries by 1992.

In the late 1980 s, IBES extended its coverage abroad with an international data base that includes Japan. Although the data base begins in 1987, the Japanese IBES data did not achieve wide coverage of companies until 1989 and 1990 and have only recently received widespread attention by Japanese market participants. Also, Japan has fewer suppliers of forecast data than does the 
United States. The lack of adequate historical Japanese IBES data restricts our ability to do retrospective examination of Japanese forecasts based solely on IBES.

An industry standard for earnings forecasts in Japan that has been available for years is the Toyo Keizai Corporate Profit Forecast. Virtually the entire securities industry in Japan uses these quarterly EPS forecasts, and they are the standard against which practitioners gauge announced earnings. Rather than being a compilation of individual analyst forecasts (as in IBES), Toyo Keizai forecasts begin with a questionnaire sent to companies about a month and a half prior to forecast publication. Each company is asked to respond within two weeks with its company forecast of current and next-fiscal-year EPS. After follow-ups by telephone and occasional field visits, Toyo Keizai produces a final forecast. In the vast majority of cases, Toyo Keizai takes the company's forecast of current-year earnings as its final forecast, with an occasional (5 to 10 percent of cases) subjective adjustment for companies that have had a significant pattern of past forecast errors.

The Japan Company Handbook, published quarterly since 1988, provides the English language version of the Toyo Keizai earnings forecasts, as well as extensive financial and descriptive information on Japanese companies. Its Japanese language equivalent, the Kaisha Shikiho, has been available much longer. Appendix B provides a brief description of the Handbook.

An alternative source of earnings forecasts is the Kaisha Joho, published by Nikkei. Like the Japan Company Handbook, the Kaisha Joho is a quarterly paperback that includes a wide array of company information and forecasts. In many discussions with analysts and users of analysts' forecasts, the Toyo Keizai forecasts were consistently cited as the more widely used of the two series. As a result, we focus on the Toyo Keizai forecasts as the industry standard for Japan. ${ }^{7}$

Comparison of Forecasts in the United States and Japan. A perception in the popular press is that Japanese analysts' forecasts are very accurate- -by implication, more accurate than those produced in the United States. For instance, a recent book by a senior research analyst at a leading Tokyo securities firm and the business editor of the Far Eastern Economic Review refers to Japanese analysts' forecasts and their link to industry standards supplied by Toyo Keizai and Nikkei as follows:

These forecasts are usually made, unofficially, by the companies

\footnotetext{
${ }^{7}$ Zielinski and Holloway (1991) provide a discussion of various sources of financial information in Japan, including the Toyo Keizai and Nikkei earnings forecasts.
} 
themselves and form the basis for what is known as the street estimates. An earnings surprise for a company can be discerned simply by comparing the actual figures that appear in the latest edition with the forecast in the previous one.

Japanese companies feel obliged to meet their profit forecasts, so the estimates that appear are remarkably dependable. By looking at the growth rates in recurring profits, it is also possible to find the most rapidly expanding companies and industries to know, with reasonable accuracy, which sectors investors will pay attention to over the coming year or two. All this makes life untaxing for securities analysts in Japan. If they so choose, they could simply use the forecasts that appear in the two information books, adding or subtracting a little here and there to reflect their own expectations for a company's earnings. (Zielinski and Holloway 1991, p.92)

This description, however, does not capture some of the recent developments that are causing a transition in the role Japanese analysts may play in the future.

As in the United States, all the major Japanese security houses have analysts who produce earnings forecasts (usually for client use). Historically, major Japanese securities firms have had close ties with Japanese companies and have garnered substantial income from equity underwriting. This link resulted in the practice of avoiding negative positions on a stock in. order to maintain good relations with the company. Security houses often limited analysts' independence, and until 1993, all major Japanese securities houses had a policy of not making sell recommendations.

Spurred by competition from U.S. and European houses and scandals in the Japanese markets, major Japanese securities firms have been instituting stock-rating systems that include negative recommendations. Moreover, there is a movement to upgrade the independence, training, and professional standing of analysts in Japan. Based on information from our interviews in Japan with producers and users of earnings forecasts, Japanese analysts have historically been spread thin by U.S. standards. A single analyst has often covered $40-50$ stocks, possibly spanning a number of industries. Such a range of coverage can be particularly burdensome during the flurry of earnings announcements clustered after the end of the fiscal year. This onslaught of new information may require an analyst to spread follow-up study of a report over a period of time. Adding to this picture have been assignment policies that rotate analyst stock responsibilities every two to five years. Thus, historical practices and culture in Japan have not promoted the professional development and expertise of analysts. 
A sampling illustrates the Japanese financial press's view of developments:

- Nikkei News Bulletin, July 6, 1992. "Brokerage houses increasingly give a clear 'buy' or 'sell' recommendation on a given issue in their reports. Previously, when they wanted to recommend the sale of a certain stock they often just removed it from their recommendation lists."

- The Nikkei Weekly, July 25, 1992. "Securities analysts are gaining popularity and prestige in Japan as market players, stung by the steep tumble of Tokyo stocks, are seeking professional advice. In contrast to the independent image of their U.S. counterparts, Japanese analysts have been perceived as tightly tied into their corporate structures, dispensing recommendations in line with those of their companies' sales departments. Consequently, market players tended to pay analysts scant attention until a series of brokerage scandals broke last year. Now, recognition of the importance of information in formulating intelligent investment strategies is leading market players to consult analysts about market movements and corporate earnings projections.

"In mid-June, for example, the stock prices of Japan's major steel producers fell sharply across the board in response to disappointing earnings projections for them released by the research institutions affiliated with Japan's Big Four brokerages. The securities houses' projections varied dramatically from the steelmakers' own forecasts."

- The Nikkei Weekly, July 25, 1992. "As investors gain access to more information and become more astute at analyzing it themselves, they are demanding more and more sophisticated information from analysts ... In line with this new professionalism, Nomura Research Ltd. plans to introduce an analyst-evaluation system based on objective data by the end of the year. Even before undergoing such an in-house evaluation, however, analysts must pass examinations organized by the Securities [sic] Analysts Association of Japan. A total of 13,915 candidates took the preliminary and secondary examination this year, the tenth consecutive year the number of test takers has risen. A mere 483 took the exams in 1983."

- The Nikkei Weekly, October 12, 1992. "Ironically, scandals resulting from overly cozy relations between securities houses and clients are sparking more objective and critical analysis. Research departments increasingly are being freed from intervention by other company divisions ... Given that there are now more than 4,000 charter members in the analysts' association (Securities [sic] Analysts Association of Japan), it is not surprising that competition for insightful—and money-making-research is increasing."

- The Nikkei Weekly, October 4, 1993. "After years of resistance, Japan's major securities companies are preparing to make 'sell' stock recommenda- 
tions to their clients. Such recommendations have long been given by most non-Japanese brokerage houses, but not in Japan, where customers have often been encouraged to buy a favorite share but rarely to sell a poorly performing issue. In January, the Nomura Research Institute Co., an affiliate of brokerage giant Nomura Securities Co., broke this decades-long taboo in a bid to meet global standards and to resurrect its tarnished image. Now research bodies of Japan's other Big Four brokerage houses ... . are preparing to start rating individual stocks and to advise clients to sell shares, if warranted."

Because our main focus is on Toyo Keizai forecasts and our data go only through 1992, we cannot provide much evidence on how these changes for Japanese analysts actually have affected the performance of analysts at Japanese securities houses. Nonetheless, assessments for the future must keep these important developments in mind.

\section{Prior Research on Japanese Earnings and Earnings Forecasts}

In the United States, an immense amount of literature is available on earnings, earnings forecasts, and stock prices. Earnings forecasts by U.S. financial analysts are more accurate than extrapolative models based on past data, especially when a consensus of analysts' forecasts is used (see, for example, Conroy and Harris 1987). U.S. analysts appear to be overly optimistic in their forecasts, however, and prone to exaggeration (DeBondt and Thaler 1990; Boebel 1991). Analysts' forecasts also appear to be significantly linked to the pricing of U.S. equities (see, for example, Elton, Gruber, and Gultekin 1981). Givoly and Lakonishok (1984) and Brown, Foster, and Noreen (1985) provide useful surveys of early work. Brown (1993) reviews recent research in the United States, and IBES (1992) provides an extensive bibliography of papers using IBES data on analysts' earnings forecasts.

In contrast, comparatively little research is readily available on Japanese earnings forecasts and how markets react to earnings and earnings forecasts. The paucity of research available to Western readers is exacerbated by language differences and the proprietary nature of some work done by Japanese securities firms. Much of the work that is available on Japanese markets directly parallels seminal research in the United States. Although the popular press often discounts the role of earnings in Japanese equity pricing, a review of the empirical evidence shows that earnings and earnings forecasts play an important role in Japanese equity markets.

Earnings and Share Prices. Beaver (1968) conducted a key early study of the link between earnings and stock prices in the United States. Using 
weekly data, he found that both price and volume react to annual earnings announcements. This link was interpreted as showing that earnings announcements contain information. Parallel studies on the TSE by Ishizuka (1978) and Ohtsuka (1981) (using weekly data and the Beaver methodology) produced results for the TSE that were similar to Beaver's for the United States. ${ }^{8}$

Ball and Brown (1968) took Beaver's work one step further in the United States. Their premise was that, if accounting earnings contain information about economic value, a positive relationship will exist between unexpected earnings and unexpected stock price changes. Their results supported this contention. In Japan, Satoh (1979) and Kubota (1980) applied the Ball and Brown methodology to TSE-listed stocks using monthly data and found results in Japan similar to the U.S. findings. In an early study using daily data, Kobayashi (1975) found no link between the sign of earnings changes and abnormal stock returns, but subsequent work on Japanese daily returns supported the link between earnings surprises and stock prices. Using daily data for the 1978-84 period, Sakakibara et al. (1988) examined the market reaction to earnings surprises for both consolidated and unconsolidated earnings announcements. ${ }^{9}$ Proxying earnings expectations with a modification of a simple random walk model (5 percent expected growth from last year) and defining an earnings surprise as a deviation from this forecast, the authors found significant abnormal returns in reaction to earnings surprises for both unconsolidated and consolidated announcements. In addition, they found that the market is slow in fully adjusting to the information in consolidated earnings. They reported evidence that a profitable trading opportunity could be based on investing after the public announcement of earnings, suggesting a market inefficiency.

Analysts' Earnings Forecasts and Share Prices. Again paralleling developments in the United States, recent Japanese studies have examined the role of analysts' and management forecasts. Elton and Gruber (1989) studied earnings forecasts made by one securities firm, Nomura, for 1985 and 1986. They found that earnings have larger effects on share prices than do

\footnotetext{
${ }^{8}$ Most of the discussion on the studies of the Japanese market that have been published in Japanese is drawn from Sakakibara et al. (1988).

${ }^{9}$ Chapter 4 of Sakakibara et al. (1988) deals with the information content of accounting numbers. This chapter was written by Hisakatsu Sakurai and, according to the introduction, represents a summary and extension of his extensive work on the information content of earnings, which has been published in Japanese. See Sakakibara et al. for a full listing of his work.
} 
sales, counter to some claims about the revenue orientation in Japanese markets. These results are similar to a number of findings for the United States. Elton and Gruber found that analysts' forecasts play an important role in equity pricing in that "knowledge that forecasts were in error produced larger positive excess returns than knowledge of the actual values of the variables themselves" (p. 289). They also noted that excess returns can be earned by buying stocks after an upward revision in analysts' forecasts. The Nomura estimates, however, are typically available only to Nomura customers and might not be publicly available on a timely basis to exploit this trading opportunity. Also, the study's time frame does not cover the Japanese boom and crash in the late 1980s and early 1990s. Nonetheless, Elton and Gruber showed the importance of the link between analysts' earnings forecasts and Japanese share prices.

Darrough and Harris (1991) focused on Japanese management forecasts for the $1979-87$ period. The major portion of their sample (84 percent) is concentrated in the 1985-87 subperiod. Using analysts' forecasts from Nikkei, as well as management forecasts reported in the Nihon Keizai Shinbun, they found only a weak association between earnings surprises (measured as announced earnings minus analyst forecasts) and abnormal share returns. In contrast, they found that, even controlling for the contemporaneous announcement of past earnings, management forecasts are significantly linked to share prices. The association they found may be understated, however, because they compared management forecasts to historical earnings rather than to current analyst forecasts.

Conroy, Harris, and Park (1993b) studied Japanese companies in the first section of the TSE during the 1985-90 period. They found that stock prices react to announcements of recent earnings when such earnings differ from analysts' forecasts. Furthermore, they detected a much stronger price reaction to concurrent announcements of management forecasts of next year's earnings when such management forecasts deviated from beliefs analysts previously held. Unlike Elton and Gruber, Conroy et al. used Toyo Keizai forecasts, which are publicly available in the financial press. They concluded that earnings fundamentals are priced in the Japanese market and that management forecasts of earnings convey significant information to market participants. They also cited evidence that the role of earnings in Japanese pricing appears to be increasing in recent years.

Other Research. In addition to the direct evidence using firm-specific earnings announcements and forecasts, recent research also reinforces the important role that fundamental information plays in the pricing of Japanese 
equities. Chan, Hamao, and Lakonishok $(1991,1993)$ conducted an extensive study of monthly Japanese stock returns for the 1971-88 period. They concluded that there is "significant relation between returns in the Japanese market and four fundamental variables-earnings yield, size, book-to-market ratio and cash flow yield" $(1993$, p.68). They noted, however, that the effect of earnings yield and size disappear after controlling for the other variables. Book-to-market ratio has the largest single effect. The authors suggest that the relatively weaker explanatory power of their earnings variable may result from noise that may be induced by the events of a single year or from the fact that earnings are more easily manipulated than other variables.

In a different vein, Kaplan (1992) provided evidence of the importance of corporate earnings in Japanese markets. He found that top-executive turnover in Japan is affected by all three measures of financial performance studiedstock price, sales, and earnings. He concluded that "the relations between managerial rewards and performance are surprisingly similar in Japan and the United States" and that "earnings measures tend to explain the most variation in turnover and compensation in Japan while sales measures tend to explain the most in the United States" (p.3). The importance of earnings for Japanese managers underscores their role in corporate activity.

Scant evidence is available on the forecasting ability of Japanese analysts. To our knowledge, the only prior work in the area is Conroy, Harris, and Park (1993a), which examined the accuracy of Toyo Keizai forecasts during the 1985-88 period. The current research updates (through 1992) and extends that earlier work in a number of dimensions, including analysis of industry composition, the role of negative earnings, possible forecast bias, and new IBES data in Japan.

\section{Approach and Methodology}

In assessing and interpreting analysts' accuracy in Japan and comparing it with that found in the United States, we pursue five general themes: different forecasting challenges across companies in the two countries, consensus benefits of aggregating individual forecasts, management information available to analysts, analysts' forecasting ability, and analysts' incentives.

- Forecasting challenges. Earnings of Japanese companies may be easier to predict than those of U.S. firms. Prior research has shown the importance of differences in firm characteristics when examining forecast accuracy (see, for example, Conroy and Harris 1987; Rivera 1991). Among the sources of difference between the United States and Japan are the industry composition of companies in the two countries, accounting standards that may provide Japanese firms more opportunity to mask shortfalls in firm performance, and 
more diversification by Japanese firms across industries and national markets than their U.S. counterparts. In our empirical work, we address the possibility of differential forecasting challenges in two ways. We look at analysts' forecast errors, controlling for some differences between U.S. and Japanese firms. Then, we focus solely on Japanese companies but use two separate sources of analysts' forecasts.

- Consensus benefits. Because the IBES forecasts are the means of individual analyst projections, any consensus benefits of averaging will reduce forecast errors measured against the IBES forecasts. No such averaging is in the Toyo Keizai forecast, so consensus benefits found in earlier work (for example, Conroy and Harris 1987) would favor IBES forecast accuracy over that from Toyo Keizai. As already mentioned, however, U.S. IBES forecasts are less (not more) accurate than Japanese Toyo Keizai projections. In comparing Japanese IBES with Toyo Keizai, we explicitly control for the number of analysts following a stock.

- Management information. A potential source of Toyo Keizai forecasts' accuracy is their incorporation of management information through questionnaires. In the United States, management earnings forecasts provide analysts with valuable information (Hassell, Jennings, and Lasser 1988; Baginski and Hassell 1990). Management information may be particularly important if Japanese managers have flexibility and incentive to meet their own forecasts. For instance, Kaplan (1992) showed that, contrary to some speculation, Japanese managers have large financial performance incentives. Although U.S. analysts have substantial contact and communication with corporations, the precise tie in the Japanese system does not exist in the United States. If the benefits of management information are substantial, one would expect Toyo Keizai forecasts to be more accurate than analyst forecasts in the United States.

- Analyst forecasting ability. Behavioral studies suggest that individuals are often prone to optimism and exaggeration in a variety of decisions (see, for example, Kahneman and Tversky 1973; Weinstein 1980). Using U.S. IBES data, DeBondt and Thaler (1990) provided empirical evidence of such optimism and exaggeration in analysts' forecasting (see also Boebel 1991; Brown 1993). They also cited other empirical support for deviations from "rational" forecasts in a wide array of forecasting settings such as prediction of macroeconomic variables. Overoptimism by analysts could produce consistently positive forecast errors and/or exaggeration as analysts overweight extreme outcomes. We have no reason to expect, however, that the behavior of Japanese and U.S. analysts would differ significantly in this respect. Of course, the fact that historical practices in Japan have not promoted the professional development and expertise of analysts to the same extent as in the United 
States would favor superior forecasting in the United States.

- Analyst incentives. An agency problem may exist for sell-side analysts working for brokerage houses that make money by stimulating trading activity. In such cases, analysts may have incentive structures that reward optimism on a stock more than they reward correct calls on poor earnings performance. Response to these incentives would reduce average forecast accuracy and make forecasts unduly optimistic. Such incentives might explain prior findings of overoptimism in U.S. IBES forecasts, because they are from sell-side analysts. In contrast, Toyo Keizai is an information provider that is not engaged in making recommendations for stock selection. As a result, if such incentive problems exist, they might explain differences between Toyo Keizai forecasts in Japan and IBES forecasts in the United States. We shed some light on these incentive problems by a direct comparison of Toyo Keizai and Japan IBES forecasts for the same Japanese companies.

Sample and Data. The Japanese companies in our data base are all those in the first section of the TSE with fiscal years ending in March (the most common choice in Japan) for which both actual earnings and earnings forecasts are available in a given year. Actual earnings data are from the Nikkei Needs Data Base; forecasts are from the Japan Company Handbook and the Kaisha Shikiho. ${ }^{10}$ In keeping with Japanese industry practice, we use unconsolidated (parent-only) earnings.

For comparison purposes, we select all New York Stock Exchange (NYSE) firms with a December fiscal year (the common choice in the United States) having data on both actual earnings and earnings forecasts in a given year. In the United States, the source of earnings forecasts is IBES; actual earnings (without extraordinary items) are from COMPUSTAT.

The first section of the TSE has about 85 percent of the trading volumes and values on the TSE (Ziemba 1991), and the NYSE captures about 85 percent of the market value of listed U.S. shares (French and Poterba 1991). Thus, our samples are reasonable proxies for the entire markets in both countries, although the data requirements favor larger, well-followed firms. Our selection procedures yield, on average, more than 700 companies a year in each of the two countries.

For earnings forecasts in the United States, we use December mean forecasts (average across individual analysts) of EPS for the current fiscal year and the subsequent fiscal year. For instance, as of December 1985, IBES

\footnotetext{
${ }^{10}$ We used the April publication of the Japan Company Handbook; for data prior to 1988, we used the Kaisha Shikiho.
} 
reports a mean forecast for a company's 1985 EPS (the actual to be reported in the upcoming months), as well as for its $1986 \mathrm{EPS}$. The industry standards for Japan are the March Toyo Keizai earnings forecasts for the current fiscal year and for the subsequent fiscal year.

For each company for each fiscal year's EPS, three separate forecasts are used, resulting in three distributions of forecast errors. The current-year forecasts are analyst forecasts made in the last month of the fiscal year about to end. For instance, in the case of Japan, a forecast of fiscal year 1986 (ending in March 1986), which is made in March 1986, is the current-year forecast. At this forecast date, analysts should have substantial information about the likely earnings figure. The next-year (one-year-ahead) forecasts are analyst forecasts made one year in advance of the end of a fiscal year. For Japan, for example, the next-year forecast for the 1986 fiscal year would have been made in March 1985. The third forecast is a simple random walk forecast that assumes no change in EPS from the previous year.

The nine-month lag between the ends of the fiscal years for Japanese (March) and U.S. (December) companies creates difficulties for comparison because economic conditions may change during that interval. To provide for a more timely match, we adopt the convention of comparing Japanese March fiscal years with the U.S. fiscal year ending three months earlier. Thus, the comparison would be, for example, between the 1991 Japanese fiscal year and the 1990 U.S. fiscal year. For expositional convenience, the reference year will refer to the relevant Japanese year; that is, a reference to 1991 would denote the 1991 Japanese fiscal year ending in March 1991 and the U.S. fiscal year ending in December 1990. The effect of this convention is that 1991 will refer to earnings that will be announced in calendar 1991.

Forecast Error Measurement. As a first step in understanding forecasting accuracy in the two countries, we adopt the adage that "a picture is worth a thousand words." We first examine a prediction-realization diagram, which illustrates both the magnitude and direction of forecast errors. This approach provides extensive insights into the nature of forecast accuracy but offers no direct statistical tests of the significance of the forecast errors observed. ${ }^{11}$

To address the issue of forecast accuracy without distinction between

\footnotetext{
${ }^{11}$ We thank Rick Boebel for suggesting use of such plots. Drawn from Thiel (1966), the prediction-realization diagram is used by Boebel (1991) in an extensive investigation of U.S. analyst forecasts. For a discussion of the other error metrics we used, see Givoly and Lakonishok (1984).
} 
positive and negative errors, we examine absolute percentage errors. For each company for each year, we compute an absolute percentage forecast error in EPS, defined as the absolute value of the difference between the forecast and actual divided by the absolute value of the actual. These absolute forecast errors are then averaged across companies to construct a mean absolute percentage forecast error (MAPE). The MAPE represents the average ability to forecast EPS. Companies with absolute percentage forecast errors above 2.0 (200 percent) are assigned a value of 2.0 in order to avoid having outliers distort the reported averages. ${ }^{12}$ To provide further information on the distribution of forecast errors, we report percentiles of the distribution.

To examine possible biases in the forecasts, we repeat this procedure using signed forecast errors. The mean of these signed percentage errors (MSPE) indicates either optimism (positive errors) or pessimism on the part of analysts.

As a final exploration of the patterns in forecast errors, we use cross-sectional regression analysis of the form

Actual $=\alpha+\beta$ (Forecast $)+v$,

where actual denotes a company's realized EPS, forecast denotes the forecast of EPS, alpha $(\alpha)$ and beta $(\beta)$ are coefficients to be estimated, and $v$ is a random error term with mean zero. If forecasts are unbiased, rational estimates of actual outcomes, alpha should be 0 and beta should be 1 . Graphically, this result (alpha $=0$, beta $=1$ ) would be a 45 -degree line on which actuals equal forecasts. A negative value of alpha would indicate overoptimism on the part of analysts as actuals fall short of predictions. A beta below unity indicates that analysts exaggerate as actuals are damped below the projected values.

These regressions are estimated for each country for each year in the study period. To test the proposition that alpha equals zero over a number of years, we calculate a $t$-statistic as the mean of the annual alpha values divided by the standard deviation (across years) of those annual values. A similar procedure is used to test whether beta is different from unity over a number of years.

\section{Empirical Results: Forecast Accuracy and Bias}

In this section, we use a graphic portrayal of actual versus forecast earnings to illustrate our key conclusions. We then focus more carefully on forecast accuracy by examining the mean absolute percentage errors for each year in

\footnotetext{
${ }^{12}$ We used the MAPE rather than a mean squared error because the latter gives a very high weight to large errors. Previous research showed that share price responses to analysts' forecast errors (in both the United States and Japan) are somewhat dampened for large errors (Conroy, Harris, and Park 1993b). Use of the MAPE and the convention of assigning a maximum error of 200 percent avoid giving too much weight to a few very large forecast errors.
} 
the 1985-92 period. Finally, we examine whether the forecasts appear unduly optimistic or pessimistic.

Patterns in Actual and Predicted Earnings. Figure 2 illustrates realized-prediction diagrams for current-year forecasts over the entire study period. A 45-degree line is sketched in both panels to show the pattern that would arise if forecasts were perfectly accurate. The graphs are scaled so that, for a country, the maximum value on an axis is ten times the mean value of the variable for that country. For instance, in Japan, 400 yen is approximately ten times the sample average for forecasted earnings per share in Japan. ${ }^{13}$ Figure 3 plots realizations and predictions made one year ahead.

The patterns in Figure 3 are easier to see than those in Figure 2 because of the increased dispersion of the points as accuracy diminishes with an increase in the forecast horizon. As a result, we focus on Figure 3 to portray the following key conclusions:

- Forecasts are more accurate in Japan than in the United States. For Japan, the points in Figure 3 lie reasonably tightly grouped around the 45-degree line, whereas they exhibit much more dispersion for the United States.

- Forecast errors increase with the length of the forecast horizon in both countries. Comparison of Figures 2 and 3 shows that points are farther from the 45-degree line in Figure 3 using one-year-ahead forecasts.

- IBES forecasts in the United States appear to be overly optimistic. For the United States, the bulk of the plotted points lie to the right of the 45-degree line, indicating that the forecasts exceed the realized earnings.

- This pattern of overoptimism is not apparent in Japanese data. For Japan, the points are more clustered near the 45-degree line than in the U.S. diagram.

- Analysts seldom forecast negative earnings. The result is large forecast errors when companies have negative earnings. Such large errors are more pronounced in the United States than in Japan, as shown by a comparison of the points in the southeast quadrants in Figure 3.

Forecast Accuracy Measured by Absolute Forecast Errors. T 0 provide stronger support for the conclusions just articulated, we turn to MAPEs

\footnotetext{
${ }^{13}$ Scaling the axes in this fashion eliminated less than 1 percent of our data (a few very large observations) and does not change the conclusions reached. For instance, in the Japanese data, the screen eliminated 16 out of 6,154 current-year forecasts; for the United States, the screen eliminated 44 of 6,192 current-year forecasts. In the following sections, which use percent errors, these observations are included.
} 
FIGURE 2. Actual and Current-year Forecasts of Earnings per Share in Japan and the United States, 1985-92
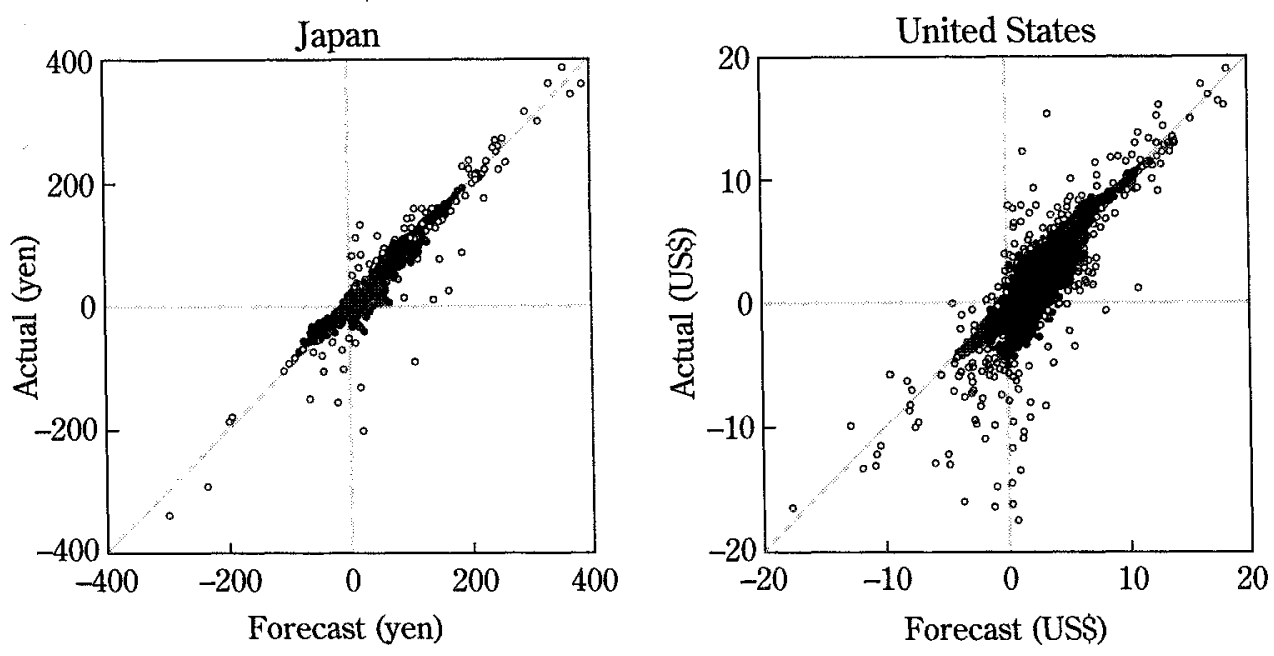

Note: Forecasts in Japan are Toyo Keizai earnings forecasts made in the last month of the fiscal year about to end. Forecasts in the United States are mean IBES forecasts in the last month of the fiscal year about to end.

FIGURE 3. Actual and One-year-ahead Forecasts of Earnings per Share in Japan and the United States, 1986-92
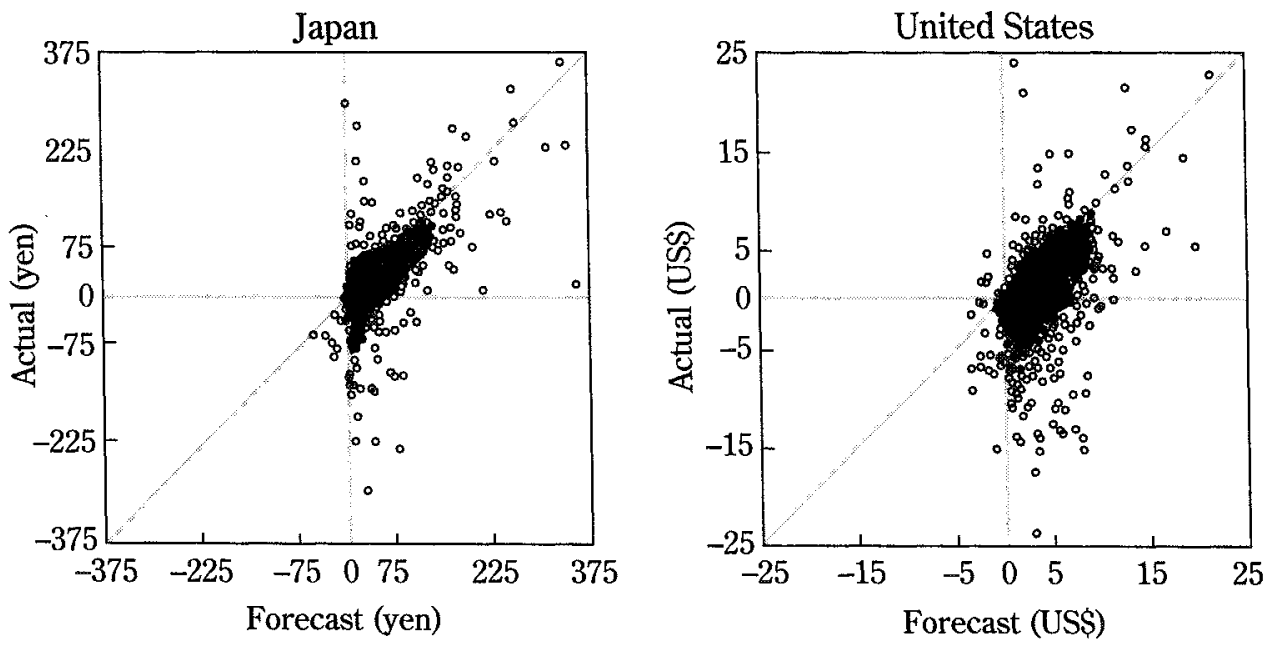

Note: Forecasts in Japan are Toyo Keizai forecasts made one year ahead of the fiscal year end. Forecasts in the United States are mean IBES forecasts one year ahead of the fiscal year end. 
for a detailed statistical analysis of forecast errors.

- Current-year forecasts. Table 3 shows current-year forecast errors. The mean forecast errors indicate that the Toyo Keizai forecast errors are significantly lower than the IBES errors in each year. For instance, in 1991, the mean forecast error in Japan is 0.133 (13.3 percent), about a third of the U.S. figure of 0.391 . The $t$-value comparing the two is 11.78 . The Japanese errors are also less variable, as shown by the lower standard deviations.

The percentile values on the right side of Table 3 demonstrate that the differences between the two countries, in large part, result from the ability of Toyo Keizai to avoid very large errors rather than to uniform, across-the-board superiority in forecast accuracy. For instance, about 10 percent of IBES errors exceed 1.00 as shown by the 90 th percentile values, whereas the 90 th percentile values in Japan are less than 0.50 in all but one year. In both countries, half the companies have forecast errors of 0.10 or less, as shown by the median errors for the 50th percentile.

Table 3 suggests that, if anything, the differential accuracy of forecasts between Japan and the United States has become more pronounced in the later

\section{TABLE 3. Current-Year Mean Absolute Percentage Errors (MAPE) of Earnings per Share Forecasts for Japanese and U.S. Companies, 1985-92}

\begin{tabular}{|c|c|c|c|c|c|c|c|c|}
\hline \multirow[b]{2}{*}{ Year } & \multirow[b]{2}{*}{$\mathrm{N}$} & \multirow[b]{2}{*}{ Mean } & \multirow{2}{*}{$\begin{array}{l}\text { Standard } \\
\text { Deviation }\end{array}$} & \multicolumn{5}{|c|}{ Percentiles } \\
\hline & & & & $90 \%$ & $75 \%$ & $50 \%$ & $25 \%$ & $10 \%$ \\
\hline \multicolumn{9}{|c|}{ Japan, Toyo Keizai (March forecast of March fiscal year end) } \\
\hline 1985 & 598 & 0.170 & 0.331 & 0.400 & 0.155 & 0.059 & 0.017 & 0.005 \\
\hline 1986 & 700 & 0.243 & 0.446 & 0.588 & 0.203 & 0.078 & 0.024 & 0.008 \\
\hline 1987 & 739 & 0.193 & 0.339 & 0.468 & 0.187 & 0.075 & 0.024 & 0.005 \\
\hline 1988 & 793 & 0.166 & 0.298 & 0.387 & 0.170 & 0.068 & 0.023 & 0.009 \\
\hline 1989 & 791 & 0.116 & 0.211 & 0.236 & 0.127 & 0.062 & 0.023 & 0.007 \\
\hline 1990 & 845 & 0.099 & 0.171 & 0.214 & 0.101 & 0.043 & 0.019 & 0.005 \\
\hline 1991 & 831 & 0.133 & 0.269 & 0.255 & 0.133 & 0.057 & 0.022 & 0.007 \\
\hline 1992 & 856 & 0.198 & 0.352 & 0.480 & 0.181 & 0.077 & 0.027 & 0.008 \\
\hline \multicolumn{9}{|c|}{ U.S., IBES (December forecast of December fiscal year end) } \\
\hline 1985 & 680 & 0.292 & 0.473 & 0.985 & 0.317 & 0.063 & 0.020 & 0.007 \\
\hline 1986 & 698 & 0.369 & 0.566 & 1.150 & 0.500 & 0.078 & 0.020 & 0.007 \\
\hline 1987 & 723 & 0.378 & 0.567 & 1.142 & 0.514 & 0.089 & 0.023 & 0.007 \\
\hline 1988 & 747 & 0.356 & 0.545 & 1.192 & 0.386 & 0.094 & 0.027 & 0.009 \\
\hline 1989 & 790 & 0.327 & 0.526 & 1.006 & 0.373 & 0.075 & 0.018 & 0.006 \\
\hline 1990 & 814 & 0.332 & 0.527 & 1.057 & 0.384 & 0.079 & 0.021 & 0.006 \\
\hline 1991 & 859 & 0.391 & 0.581 & 1.297 & 0.493 & 0.097 & 0.025 & 0.008 \\
\hline 1992 & 881 & 0.431 & 0.607 & 1.500 & 0.612 & 0.120 & 0.025 & 0.006 \\
\hline
\end{tabular}

Note: All absolute errors above 2.0 (200 percent) are given a value of 2.0 . 
sample years. For instance, the 50 th percentile values for Japan and the United States in the mid-1980s are quite close. For 1990 to 1992, however, the Japanese median errors are considerably smaller than those in the United States.

- One-year-ahead forecasts. Table 4 presents the results of the more difficult forecasting challenge of predicting EPS a year into the future. Because the forecast data began in 1985, we examine these forecasts beginning with 1986.

As expected, the errors in Table 4 are significantly larger than the currentyear forecast errors in Table 3 . Table 4 also shows that one-year-ahead Toyo Keizai forecasts are more accurate than the IBES forecasts. For instance, in 1986, the Japanese mean error of 0.480 is significantly less $(t=4.21)$ than the U.S. mean of 0.631 . As was true for the current-year forecasts in Table 3 , the percentile values on the right of Table 4 suggest that a primary reason for the difference between the two countries is the greater frequency of very large forecast errors in the United States. Note, however, that the practice of setting a maximum error of 2.0 mitigates the effect of any single error on sample averages.

TABLE 4. One-Year-Ahead Mean Absolute Percentage Errors (MAPE) of Earnings per Share Forecasts of Japanese and U.S. Companies, 1986-92

\begin{tabular}{|c|c|c|c|c|c|c|c|c|}
\hline \multirow[b]{2}{*}{ Year } & \multirow[b]{2}{*}{$\mathrm{N}$} & \multirow[b]{2}{*}{ Mean } & \multirow[b]{2}{*}{$\begin{array}{l}\text { Standard } \\
\text { Deviation }\end{array}$} & \multicolumn{5}{|c|}{ Percentiles } \\
\hline & & & & $90 \%$ & $75 \%$ & $50 \%$ & $25 \%$ & $10 \%$ \\
\hline \multicolumn{9}{|c|}{ Japan, Toyo Keizai (March forecast of next March) } \\
\hline 1986 & 584 & 0.480 & 0.565 & 1.399 & 0.661 & 0.244 & 0.105 & 0.015 \\
\hline 1987 & 685 & 0.511 & 0.573 & 1.362 & 0.764 & 0.275 & 0.093 & 0.033 \\
\hline 1988 & 728 & 0.370 & 0.456 & 1.000 & 0.445 & 0.198 & 0.078 & 0.030 \\
\hline 1989 & 771 & 0.306 & 0.382 & 0.680 & 0.370 & 0.176 & 0.080 & 0.028 \\
\hline 1990 & 785 & 0.273 & 0.353 & 0.593 & 0.333 & 0.161 & 0.076 & 0.028 \\
\hline 1991 & 801 & 0.334 & 0.446 & 0.921 & 0.385 & 0.161 & 0.062 & 0.026 \\
\hline 1992 & 680 & 0.551 & 0.619 & 1.796 & 0.745 & 0.275 & 0.109 & 0.038 \\
\hline \multicolumn{9}{|c|}{ U.S., IBES (December forecast of next December) } \\
\hline 1986 & 678 & 0.631 & 0.708 & 2.000 & 1.096 & 0.266 & 0.080 & 0.028 \\
\hline 1987 & 693 & 0.590 & 0.678 & 2.000 & 1.000 & 0.248 & 0.071 & 0.022 \\
\hline 1988 & 720 & 0.565 & 0.664 & 2.000 & 0.911 & 0.252 & 0.074 & 0.026 \\
\hline 1989 & 749 & 0.486 & 0.618 & 1.866 & 0.630 & 0.203 & 0.072 & 0.028 \\
\hline 1990 & 772 & 0.535 & 0.661 & 1.988 & 0.810 & 0.209 & 0.065 & 0.019 \\
\hline 1991 & 812 & 0.646 & 0.699 & 2.000 & 1.100 & 0.320 & 0.087 & 0.026 \\
\hline 1992 & 848 & 0.721 & 0.730 & 2.000 & 1.308 & 0.381 & 0.092 & 0.033 \\
\hline
\end{tabular}

Note: All absolute errors above 2.0 (200 percent) are given a value of 2.0 . 
The results in Tables 3 and 4 show conclusively that, for the period studied, Toyo Keizai forecasts in Japan were more accurate than those available from IBES in the United States.

Optimism or Pessimism in Forecasts. Forecast errors may either reflect a persistent forecast bias or simply capture the inevitable errors made in trying to forecast an uncertain outcome, even if the forecaster is on-average correct. To examine whether Japanese or U.S. analysts appear to have signs of overly optimistic or pessimistic predictions, we first analyze signed percentage forecast errors in the two countries. Second, we use regression analysis to shed further light on any patterns in the forecasts.

- Mean signed percentage forecast errors. Table 5 presents MSPEs for the current-year and one-year-ahead forecasts for both countries. For the current-year forecasts, the difference between the United States and Japan is very clear. For the eight-year period, U.S. MSPEs are positive in each year and average 0.260 across the years. This sample period average is significantly different from zero $(t=5.25)$, indicating an upward bias in U.S. forecasts and confirming an optimistic bias found in earlier research using U.S. IBES data (Brown 1993; DeBondt and Thaler 1990; and Boebel 1991). In contrast, the MSPEs in Japan are negative in as many years as they are positive and average an insignificant 0.014 over the sample period. Median values of the signed forecast errors show a much lower upward bias in the United States but still are consistently positive.

One-year-ahead forecasting (the bottom half of Table 5) is more difficult than current-year forecasting. For example, Japanese analysts are forced to rely less on direct information from management. ${ }^{14}$ The optimism in the United States is even more pronounced over this longer horizon; the U.S. MSPEs are higher than for the current-year forecasts and consistently positive. In Japan, the MSPEs, on average, are higher for the one-year horizon than for the current-year forecasts but are not significantly positive over the sample period.

The results in Table 5 suggest that sell-side analysts in the United States tend to be too optimistic in their forecasts of corporate earnings. Furthermore, the large differences in the mean and median errors show that this pattern is in part attributable to some very large positive errors for some companies. A source of such errors is the apparent reluctance of analysts to predict negative

\footnotetext{
${ }^{14}$ Conversations with Japanese analysts suggest that the one-year Toyo Keizai forecasts have direct predictions from management for fewer than half of the companies.
} 


\section{TABLE 5. Signed Forecast Errors of Earnings per Share for Japanese and U.S. Firms, 1985-92}

\begin{tabular}{|c|c|c|c|c|c|c|c|c|}
\hline \multirow[b]{2}{*}{ Year } & \multicolumn{4}{|c|}{ Japan, Toyo Keizai } & \multicolumn{4}{|c|}{ U.S., IBES } \\
\hline & $\mathrm{N}$ & Mean & $\begin{array}{l}\text { Standard } \\
\text { Deviation }\end{array}$ & Median & $\mathrm{N}$ & Mean & $\begin{array}{l}\text { Standard } \\
\text { Deviation }\end{array}$ & Median \\
\hline \multicolumn{9}{|c|}{ Current-year forecasts } \\
\hline 1985 & 598 & 0.027 & 0.371 & -0.006 & 680 & 0.185 & 0.509 & 0.013 \\
\hline 1986 & 700 & 0.097 & 0.499 & -0.002 & 698 & 0.291 & 0.601 & 0.020 \\
\hline 1987 & 739 & -0.032 & 0.389 & -0.021 & 723 & 0.285 & 0.612 & 0.019 \\
\hline 1988 & 794 & -0.041 & 0.346 & -0.030 & 747 & 0.227 & 0.605 & 0.013 \\
\hline 1989 & 791 & -0.037 & 0.238 & -0.028 & 790 & 0.222 & 0.577 & 0.005 \\
\hline 1990 & 845 & -0.011 & 0.198 & -0.009 & 814 & 0.237 & 0.576 & 0.015 \\
\hline 1991 & 831 & 0.006 & 0.300 & -0.014 & 859 & 0.307 & 0.630 & 0.030 \\
\hline 1992 & 856 & 0.105 & 0.390 & 0.025 & 881 & 0.329 & 0.668 & 0.036 \\
\hline $\begin{array}{c}\text { Mean value } \\
(t)^{\mathrm{b}}\end{array}$ & & $\begin{array}{c}0.014 \\
(0.24)\end{array}$ & & & & $\begin{array}{c}0.260 \\
(5.25)\end{array}$ & & \\
\hline \multicolumn{9}{|c|}{ One-year-ahead forecasts } \\
\hline 1986 & 584 & 0.289 & 0.684 & 0.119 & 678 & 0.534 & 0.534 & 0.164 \\
\hline 1987 & 685 & 0.318 & 0.699 & 0.100 & 693 & 0.504 & 0.740 & 0.160 \\
\hline 1988 & 728 & -0.083 & 0.582 & -0.091 & 720 & 0.398 & 0.776 & 0.078 \\
\hline 1989 & 771 & -0.063 & 0.485 & -0.103 & 749 & 0.314 & 0.721 & 0.057 \\
\hline 1990 & 785 & 0.006 & 0.447 & -0.043 & 772 & 0.416 & 0.742 & 0.098 \\
\hline 1991 & 801 & 0.126 & 0.537 & -0.000 & 812 & 0.563 & 0.767 & 0.245 \\
\hline 1992 & 680 & 0.395 & 0.729 & 0.165 & 848 & 0.646 & 0.793 & 0.325 \\
\hline$\underset{(t)^{\mathrm{b}}}{\text { Mean value }^{\mathrm{a}}}$ & & $\begin{array}{c}0.141 \\
(0.72)\end{array}$ & & & & $\begin{array}{c}0.482 \\
(4.28)\end{array}$ & & \\
\hline
\end{tabular}

Note: All signed errors above 2.0 (below -2.0 ) are set equal to $2.0(-2.0)$.

${ }^{a}$ Mean of annual means.

${ }^{\mathrm{b}}$ The $t$-values test the hypothesis that mean value is zero across the years and are calculated as the mean of the annual means divided by their standard deviations.

earnings. ${ }^{15}$ Toyo Keizai forecasts in Japan do not exhibit the same strong positive bias.

- Regression analysis. The regression results presented in Table 6 echo the patterns revealed in the signed forecast errors. For Japan, the mean alpha and beta values are not reliably different from 0 and 1 , respectively, indicating that over the sample period, these current-year forecasts show no significant

\footnotetext{
${ }^{15}$ An empirical controversy is whether the earnings analysts are forecasting are the same constructs that are reported. For instance, IBES reports "actual" earnings that sometimes differ from the earnings the company actually reports. The logic for the difference is that the reported earnings figure contains some items not in the analysts' projections. We use earnings as reported by companies, which are not then adjusted ex post. We believe these to be the most objective source of earnings. To be appropriate, such ex post adjustments would have to be consistent reductions in earnings to remove the positive bias in the U.S. data.
} 
TABLE 6. Regression Analysis of Earnings Based on Current-Year Forecasts of Earnings per Share for Japanese and U.S. Firms, 1985-92.

(coefficients; $t$-values are in parentheses)

\begin{tabular}{lccccccc}
\hline & \multicolumn{3}{c}{ Japan, Toyo Keizai } & & \multicolumn{3}{c}{ U.S., IBES } \\
\cline { 2 - 4 } \cline { 5 - 7 } Year & $\alpha$ & $\beta$ & Adjusted $R^{2}$ & & $\alpha$ & $\beta$ & Adjusted $R^{2}$ \\
\hline 1985 & -0.033 & 1.006 & 0.94 & & -0.270 & 1.032 & 0.78 \\
& $(-0.09)$ & $(0.58)$ & & & $(-5.14)$ & $(1.55)$ & \\
1986 & -0.121 & 0.943 & 0.82 & & -0.492 & 1.012 & 0.52 \\
& $(-0.19)$ & $(-3.56)$ & & $(-5.56)$ & $(0.32)$ & \\
1987 & 0.420 & 1.029 & 0.94 & & -0.460 & 1.039 & 0.62 \\
& $(1.36)$ & $(3.22)$ & & $(-6.45)$ & $(1.29)$ & \\
1988 & -0.248 & 1.065 & 0.94 & & -0.393 & 1.082 & 0.73 \\
& $(0.82)$ & $(7.22)$ & & $(-5.93)$ & $(3.39)$ & \\
1989 & 0.475 & 1.022 & 0.95 & & -0.362 & 1.073 & 0.81 \\
& $(1.75)$ & $(2.93)$ & & $(-6.38)$ & $(3.90)$ & \\
1990 & 0.535 & 0.991 & 0.98 & & -0.255 & 0.975 & 0.77 \\
& $(2.77)$ & $(-1.91)$ & & $(-4.39)$ & $(-1.39)$ & \\
1991 & -0.480 & 1.033 & 0.95 & & -0.499 & 1.066 & 0.65 \\
& $(-1.36)$ & $(4.23) \mathrm{T}$ & & $(-6.64)$ & $(2.47)$ & \\
1992 & -2.83 & 1.014 & 0.91 & -0.559 & 1.046 & 0.60 \\
& $(-5.50)$ & $(1.27)$ & & $(-7.68)$ & $(1.64)$ & \\
Mean value & 0.422 & 1.013 & & -0.411 & 1.040 & \\
& $(0.41)$ & $(0.36)$ & & $(-3.72)$ & $(1.16)$ & \\
\hline
\end{tabular}

Note: The $t$-values for $\alpha$ test the hypothesis that $\alpha=0$; $t$-values for $\beta$ test the hypothesis that $\beta=1.0$. Coefficients are from the Regression Actual $=\alpha+\beta$ (forecast).

${ }^{a}$ Mean of annual coefficients with $t$-value calculated based on the standard deviation across the annual coefficients.

bias. In the United States, however, the current-year forecast mean alpha is significantly negative $(t=-3.72)$, reflecting the pattern that actual earnings fall short of the IBES forecasts.

A slightly different pattern emerges in the one-year-ahead results shown in Table 7. In Japan, the mean values of alpha and beta again are not significantly different from 0 and 1 , respectively, as measured by $t$-values shown in the last row of the table. Compared with current-year results in Table 6, however, the coefficients are farther away from the hypothesized 0,1 values, which are consistent with unbiased, rational forecasts. For the United States, the one-year-ahead results show alpha closer to zero than in the current-year figures; the mean U.S. alpha of -0.217 is not significantly different from zero $(t=-0.75)$. The beta value is much reduced, to a mean of 0.715 , which is significantly different from unity $(t=-2.06)$. This low beta value (consistent with DeBondt and Thaler 1990) suggests that analysts tend to exaggerate in their forecasts and that actuals are somewhat damped from the forecasted 
TABLE 7. Regression Analysis of Earnings Based on One-Year-Ahead Forecasts of Earnings per Share for Japanese and U.S. Firms, 1986-92.

(coefficients; $t$-values are in parentheses)

\begin{tabular}{|c|c|c|c|c|c|c|}
\hline \multirow[b]{2}{*}{ Year } & \multicolumn{3}{|c|}{ Japan, Toyo Keizai } & \multicolumn{3}{|c|}{ U.S., IBES } \\
\hline & $\alpha$ & $\beta$ & Adjusted $R^{2}$ & $\alpha$ & $\beta$ & Adjusted $R^{2}$ \\
\hline 1986 & $\begin{array}{c}0.408 \\
(0.46)\end{array}$ & $\begin{array}{r}0.825 \\
(-8.33)\end{array}$ & 0.72 & $\begin{array}{c}-0.164 \\
(-1.21)\end{array}$ & $\begin{array}{r}0.656 \\
(-7.32)\end{array}$ & 0.22 \\
\hline 1987 & $\begin{array}{c}1.024 \\
(1.28)\end{array}$ & $\begin{array}{r}0.781 \\
(-11.53)\end{array}$ & 0.70 & $\begin{array}{l}-0.183 \\
(-1.13)\end{array}$ & $\begin{array}{r}0.646 \\
(-6.21)\end{array}$ & 0.16 \\
\hline 1988 & $\begin{array}{c}0.841 \\
(0.90)\end{array}$ & $\begin{array}{r}1.072 \\
(2.48)\end{array}$ & 0.63 & $\begin{array}{c}0.210 \\
(1.22)\end{array}$ & $\begin{array}{r}0.572 \\
(-6.21)\end{array}$ & 0.10 \\
\hline 1989 & $\begin{array}{c}3.220 \\
(5.29)\end{array}$ & $\begin{array}{c}1.011 \\
(0.63)\end{array}$ & 0.81 & $\begin{array}{c}-0.239 \\
(-2.45)\end{array}$ & $\begin{array}{r}1.005 \\
(0.15)\end{array}$ & 0.55 \\
\hline 1990 & $\begin{array}{c}3.363 \\
(5.96)\end{array}$ & $\begin{array}{r}0.940 \\
(-4.00)\end{array}$ & 0.83 & $\begin{array}{r}0.068 \\
(0.59)\end{array}$ & $\begin{array}{r}0.727 \\
(-8.03)\end{array}$ & 0.37 \\
\hline 1991 & $\begin{array}{c}4.874 \\
(3.90)\end{array}$ & $\begin{array}{r}0.832 \\
(-6.00)\end{array}$ & 0.51 & $\begin{array}{l}-0.300 \\
(-2.48)\end{array}$ & $\begin{array}{r}0.729 \\
(-7.53)\end{array}$ & 0.33 \\
\hline 1992 & $\begin{array}{l}-2.834 \\
(-1.94)\end{array}$ & $\begin{array}{r}0.903 \\
(-2.77)\end{array}$ & 0.50 & $\begin{array}{c}-0.430 \\
(-3.25)\end{array}$ & $\begin{array}{r}0.671 \\
(-8.23)\end{array}$ & 0.21 \\
\hline Mean value $^{\mathrm{a}}$ & $\begin{array}{r}1.557 \\
(0.62)\end{array}$ & $\begin{array}{c}0.909 \\
(-0.86)\end{array}$ & & $\begin{array}{l}-0.217 \\
(-0.75)\end{array}$ & $\begin{array}{r}0.715 \\
(-2.06)\end{array}$ & \\
\hline
\end{tabular}

Note: The $t$-values for $\alpha$ test the hypothesis that $\alpha=0 ; t$-values for $\beta$ test the hypothesis that $\beta=1.0$. Coefficients are from the Regression Actual $=\alpha+\beta$ (forecast).

${ }^{a}$ Mean of annual coefficients with $t$-value calculated based on the standard deviation across the annual coefficients.

values. Such a pattern would be consistent with analysts overreacting to bullish prospects.

Summary. The superior forecast accuracy found in Japan may be attributable to the incorporation of management information through the Toyo Keizai questionnaire, because as shown in U.S. studies, management earnings forecasts provide analysts with valuable information (see, for example, Hassell, Jennings, and Lasser 1988; Baginski and Hassell 1990). Such management insight may offset the consensus benefits of averaging individual analyst forecasts in the U.S. IBES data. The Japanese forecasts are from a single source and thus do not benefit from the well-known improvement in forecast accuracy by aggregating forecasts (see, for example, Conroy and Harris 1987).

The finding that Japanese analysts do not exhibit the overoptimism found in the United States may arise from a number of sources. For instance, the Japanese forecasts come from Toyo Keizai and reflect the predictions of an information provider that is not engaged in making recommendations for stock selection. In contrast, the U.S. IBES forecasts come from sell-side analysts, 
who may have incentive structures that induce an upward bias if the rewards of being optimistic on a stock exceed the benefits of making a correct call on poor earnings performance.

An alternative explanation of the better accuracy of Toyo Keizai forecasts is that the earnings of Japanese companies may be easier to predict than those of U.S. firms. For instance, many Japanese firms are more diversified across industries and national markets than their U.S. counterparts. Predicting the earnings of such a diversified portfolio may be an easier task than predicting earnings for a single-industry domestic company. Rivera (1991) shows generally that earnings of diversified U.S. multinationals are easier to predict than those of typical U.S. firms. Other research has also shown the importance of differences in firm characteristics when examining forecast accuracy (see, for example, Conroy and Harris 1987). In addition, Japanese accounting standards may provide more opportunity for management to mask shortfalls in firm performance. Close cooperation among Japanese companies and between companies and the government may make corporate performance less variable and less exposed to financial hardship.

\section{Differences in U.S. and Japanese Forecasting Challenges}

One reason for the differential in forecast accuracy between Japan and the United States may be a difference in the forecasting challenge. To investigate this possibility, we examine differences in industry structure in the two countries and the role of negative earnings in increasing forecasting error. We also compare the predictive ability of a no-change (random walk) forecast with that of analysts.

Forecasting and Industry Structure. One way to examine the issue of differential forecasting in Japan and the United States is to partition by industry. Roll (1992) showed that the substantial differences in the industry composition of equity markets in different countries explain a great deal of the apparently low correlation between national market indexes. ${ }^{16}$ Industries (especially to the extent that they are globally integrated) display unique return and risk characteristics that transcend national boundaries. To the extent that the U.S. and Japanese analysts follow companies in different

\footnotetext{
${ }^{16}$ Roll showed that index diversification, industry composition, and exchange rate elements explain a large portion of the differences in the behavior of 24 national stock market indexes. In his study, industry effects had the largest explanatory power of the three factors and alone could explain about 40 percent of the volatility in a country's dollar-denominated daily index returns during the 1988-91 period.
} 
industries, they may face substantially different forecasting challenges.

We segment the sample into the seven major sectors used by the FT Actuaries/Goldman Sachs International Indexes. These indexes are published daily in the London Financial Times and cover 24 countries. Table 8 shows the seven industry sectors (see Appendix $\mathrm{C}$ for further detail) and the distribution of the sample. In number of companies, the U.S. sample is weighted more heavily toward the first four sectors (finance, energy, utilities, and transportation) than is the Japanese sample.

\section{TABLE 8. Japanese and U.S. Companies Partitioned by Industry Sector, 1985-92 Period (percentage of sample)}

\begin{tabular}{lcc}
\hline Industry Sector & Japan & United States \\
\hline Finance, insurance, \& real estate & $3.4 \%$ & $19.7 \%$ \\
Energy & 0.9 & 5.8 \\
Utilities & 2.2 & 18.2 \\
Transportation \& storage & 7.4 & 3.1 \\
Consumer goods \& services & 27.9 & 20.6 \\
Capital goods & 28.2 & 15.8 \\
Basic industries & 30.0 & 16.8 \\
\hline
\end{tabular}

Note: Industry definitions are discussed in Appendix C.

Table 9 reports one-year-ahead forecast errors partitioned by industry sector. Three conclusions stand out. First, forecast errors reflect an industry effect. Both Japanese and U.S. analysts find that some sectors are more difficult to forecast accurately than others. For instance, in both countries, focusing on the last three sectors in Table 9 , consumer goods companies are easier to forecast than the other two sectors. Capital goods industries apparently pose the most difficult challenge. Comparing the two series of sevensector numbers, the simple correlation between MAPEs in the two countries is 0.78 .

Second, in every sector, the MAPE in the United States is significantly higher than the comparable figure in Japan. For instance, the difference in forecast accuracy in consumer goods is 0.162 , which is significantly different from zero $(t=8.03)$. All such industry comparisons yield significant $t$-values, showing more accurate forecasting in Japan.

Third, differences in industry composition cannot explain the more accurate forecasts made in Japan compared with the United States. Even though industries do make a difference in forecast accuracy, Japanese forecasts are 


\section{TABLE 9. One-Year-Ahead Mean Absolute Forecast Errors of Earnings per Share of Japanese and U.S. Firms Partitioned by Industry Sector, 1985-92 Period}

\begin{tabular}{|c|c|c|c|c|c|c|}
\hline \multirow[b]{2}{*}{ Industry Sector } & \multicolumn{3}{|c|}{ Japan, Toyo Keizai } & \multicolumn{3}{|c|}{ U.S., IBES } \\
\hline & Mean & $\begin{array}{l}\text { Standard } \\
\text { Deviation }\end{array}$ & $\mathrm{N}$ & Mean & $\begin{array}{l}\text { Standard } \\
\text { Deviation }\end{array}$ & $\mathrm{N}$ \\
\hline Finance, insurance, \& real estate & 0.221 & 0.362 & 159 & 0.584 & 0.653 & 1,404 \\
\hline Energy & 0.577 & 0.542 & 45 & 0.874 & 0.753 & 441 \\
\hline Utilities & 0.244 & 0.185 & 109 & 0.381 & 0.570 & 1,354 \\
\hline Transportation \& storage & 0.397 & 0.510 & 366 & 0.865 & 0.773 & 236 \\
\hline Consumer goods \& services & 0.340 & 0.442 & 1,521 & 0.502 & 0.647 & 1,504 \\
\hline Capital goods & 0.464 & 0.542 & 1,347 & 0.716 & 0.726 & 1,196 \\
\hline Basic industries & 0.414 & 0.507 & 1,487 & 0.658 & 0.685 & 1,235 \\
\hline
\end{tabular}

Note: All absolute errors above 2.0 (200 percent) are given a value of 2.0 .

more accurate in each industry studied. In each sector, the United States mean forecast errors are half again (or more) larger than the comparable figure for Japan. ${ }^{17}$

Forecasting and Negative Earnings. We have noted previously that much of the superior forecasting accuracy in Japan was the result of having relatively few large errors and that analysts seldom make forecasts of negative earnings. Figure 4 compares forecast errors and the proportion of the sample companies that reported negative earnings for both countries. Japanese companies have been in the red much less frequently than their U.S. counterparts. In many years, fewer than 5 percent of Japanese companies have negative earnings. The proportion of negaives in Japan drifted downward in the late 1980s but rose again in 1992. In the United States, the percentage of negatives was much higher than in Japan and, for this study period, peaked in 1992.

Average forecast errors appear to be correlated with the proportion of negative earnings. How do analysts cope with prediction of what turns out to be negative earnings performance? The plots in Figure 4 show that the answer is "not very well." In both the United States and Japan, average forecast errors trend up and down with the proportion of negative earnings.

Figure 4 thus illustrates one dimension of the different forecasting challenges that U.S. and Japanese analysts faced during the sample period. To see how much effect the negative-earnings challenge has on our results, we repeat

\footnotetext{
${ }^{17}$ All three conclusions also hold for comparisons of current-year forecast errors. We do not report those detailed results here. Our data do not contain line-of-business data for Japan, and thus we are not able to analyze the issue of diversification across industries.
} 
FIGURE 4. Current-Year Mean Absolute Forecast Errors (MAPE) and Proportion of Negative Earnings Per Share
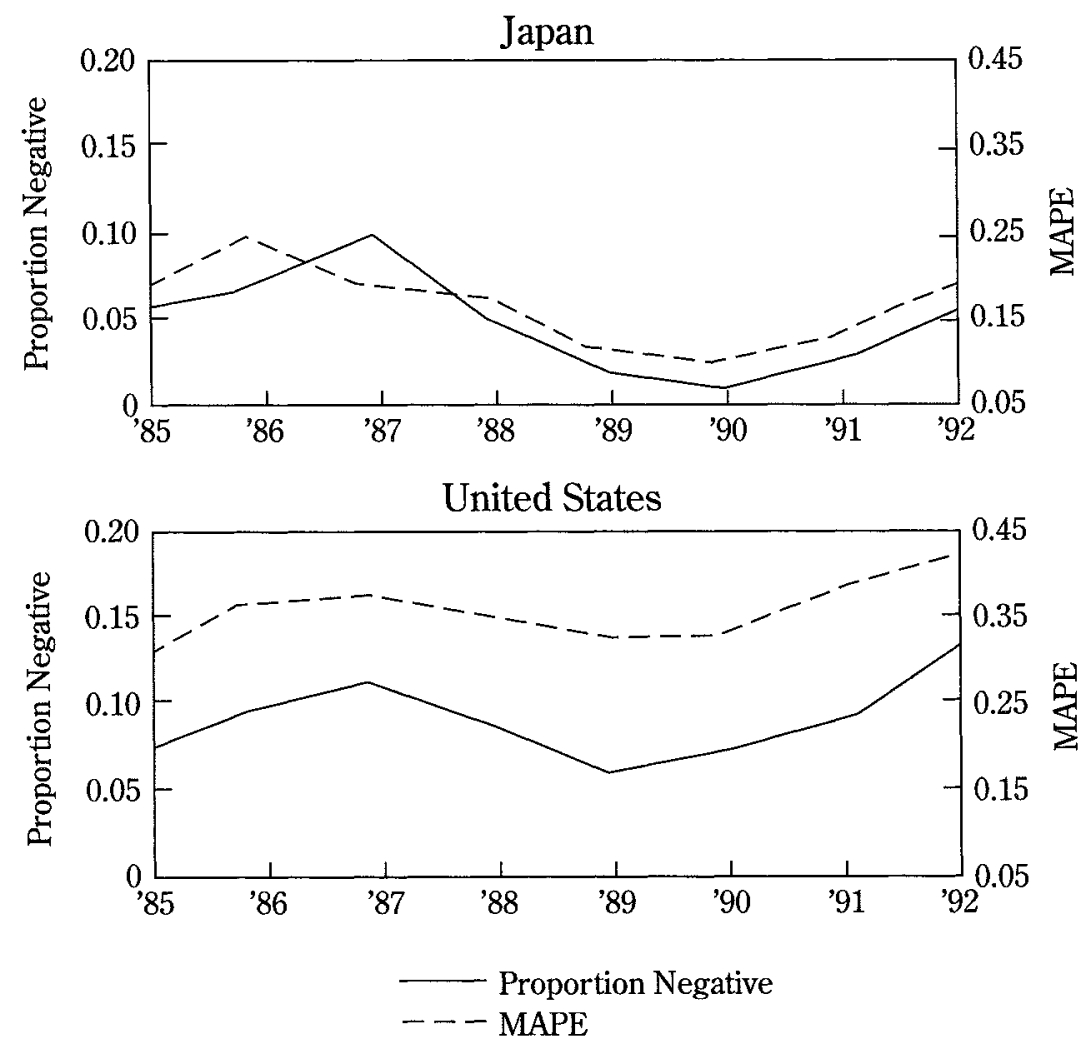

the analyses presented in Tables 3 and 4 but delete all observations with negative earnings. The results are presented in Tables 10 and 11 . These results do not mirror an actual forecasting exercise, because the analysts do not know in advance which companies will have positive earnings. Nonetheless, the results shed light on the role of negative earnings in explaining forecasting differences between Japan and the United States.

Table 10 shows that the elimination of negative-earnings companies in Japan reduces mean current-year forecast errors, but only modestly. For example, even in 1987 when the representation of negative earnings was largest, the Japanese MAPE of 0.162 is only slightly below the 0.193 figure 


\section{TABLE 10. Current-Year Mean Absolute Percentage Errors of Earnings per Share Forecasts for Japanese and U.S. Companies with Positive Earnings, 1985-92}

\begin{tabular}{|c|c|c|c|c|c|c|c|c|}
\hline \multirow[b]{2}{*}{ Year } & \multirow[b]{2}{*}{$\mathrm{N}$} & \multirow[b]{2}{*}{ Mean } & \multirow{2}{*}{$\begin{array}{l}\text { Standard } \\
\text { Deviation }\end{array}$} & \multicolumn{5}{|c|}{ Percentiles } \\
\hline & & & & $90 \%$ & $75 \%$ & $50 \%$ & $25 \%$ & $10 \%$ \\
\hline \multicolumn{9}{|c|}{ Japan, Toyo Keizai (March forecast of March fiscal year end) } \\
\hline 1985 & 566 & 0.141 & 0.283 & 0.322 & 0.136 & 0.053 & 0.016 & 0.004 \\
\hline 1986 & 657 & 0.172 & 0.315 & 0.394 & 0.170 & 0.071 & 0.022 & 0.004 \\
\hline 1987 & 671 & 0.162 & 0.303 & 0.368 & 0.153 & 0.064 & 0.021 & 0.005 \\
\hline 1988 & 751 & 0.143 & 0.246 & 0.328 & 0.159 & 0.064 & 0.023 & 0.008 \\
\hline 1989 & 775 & 0.113 & 0.205 & 0.223 & 0.125 & 0.061 & 0.022 & 0.007 \\
\hline 1990 & 838 & 0.097 & 0.165 & 0.213 & 0.106 & 0.048 & 0.019 & 0.005 \\
\hline 1991 & 810 & 0.119 & 0.234 & 0.244 & 0.126 & 0.056 & 0.021 & 0.007 \\
\hline 1992 & 808 & 0.175 & 0.324 & 0.392 & 0.167 & 0.073 & 0.026 & 0.008 \\
\hline \multicolumn{9}{|c|}{ U.S., IBES (December forecast of December fiscal year end) } \\
\hline 1985 & 622 & 0.231 & 0.413 & 0.840 & 0.205 & 0.053 & 0.018 & 0.007 \\
\hline 1986 & 612 & 0.261 & 0.463 & 0.896 & 0.249 & 0.056 & 0.017 & 0.006 \\
\hline 1987 & 626 & 0.271 & 0.484 & 0.971 & 0.267 & 0.063 & 0.019 & 0.006 \\
\hline 1988 & 668 & 0.282 & 0.478 & 0.979 & 0.273 & 0.073 & 0.024 & 0.008 \\
\hline 1989 & 722 & 0.239 & 0.418 & 0.777 & 0.246 & 0.059 & 0.017 & 0.006 \\
\hline 1990 & 741 & 0.263 & 0.453 & 0.959 & 0.245 & 0.063 & 0.018 & 0.005 \\
\hline 1991 & 763 & 0.300 & 0.497 & 0.990 & 0.319 & 0.074 & 0.021 & 0.007 \\
\hline 1992 & 736 & 0.311 & 0.512 & 0.991 & 0.331 & 0.080 & 0.019 & 0.005 \\
\hline
\end{tabular}

Note: All absolute errors above 2.0 (200 percent) are given a value of 2.0. All observations with negative earnings are deleted.

from Table 3 (which included negative earnings). ${ }^{18}$ Such modest changes reflect the relatively small number of Japanese observations deleted by the screen.

The U.S. results show a more pronounced effect of the screen for losses. Comparison of Tables 3 and 10 shows that mean current-year forecast improvements of about 0.10 (e.g., in 1986, a drop from 0.369 to 0.261 ) occur as a result of eliminating loss companies.

The striking result in Table 10, however, is that elimination of loss companies does not eliminate the apparent forecasting advantage for Japan. The current-year MAPEs for Japan are still consistently and significantly lower than those for the United States.

\footnotetext{
${ }^{18}$ We note that our convention of assigning a maximum error of 200 percent $(2.0)$ contributes to the relatively small difference in mean results. Examination of the percentile values in Tables 3 and 10 shows that the primary effect of excluding negative earnings is to eliminate very large errors.
} 
TABLE 11. One-Year-Ahead Mean Absolute Percentage Errors of Earnings per Share Forecasts for Japanese and U.S. Companies with Positive Earnings, 1986-92

\begin{tabular}{|c|c|c|c|c|c|c|c|c|}
\hline \multirow[b]{2}{*}{ Year } & \multirow[b]{2}{*}{$\mathrm{N}$} & \multirow[b]{2}{*}{ Mean } & \multirow{2}{*}{$\begin{array}{l}\text { Standard } \\
\text { Deviation }\end{array}$} & \multicolumn{5}{|c|}{ Percentiles } \\
\hline & & & & $90 \%$ & $75 \%$ & $50 \%$ & $25 \%$ & $10 \%$ \\
\hline \multicolumn{9}{|c|}{ Japan, Toyo Keizai (March forecast of March fiscal year end) } \\
\hline 1986 & 542 & 0.402 & 0.490 & 1.000 & 0.491 & 0.217 & 0.097 & 0.031 \\
\hline 1987 & 620 & 0.409 & 0.480 & 1.022 & 0.557 & 0.218 & 0.082 & 0.030 \\
\hline 1988 & 692 & 0.329 & 0.412 & 0.803 & 0.413 & 0.184 & 0.074 & 0.028 \\
\hline 1989 & 755 & 0.290 & 0.361 & 0.635 & 0.350 & 0.171 & 0.078 & 0.027 \\
\hline 1990 & 778 & 0.263 & 0.335 & 0.579 & 0.327 & 0.158 & 0.069 & 0.028 \\
\hline 1991 & 780 & 0.298 & 0.397 & 0.714 & 0.363 & 0.154 & 0.061 & 0.025 \\
\hline 1992 & 638 & 0.492 & 0.580 & 1.644 & 0.612 & 0.256 & 0.101 & 0.036 \\
\hline \multicolumn{9}{|c|}{ U.S., IBES (December forecast of next December) } \\
\hline 1986 & 591 & 0.483 & 0.615 & 1.778 & 0.666 & 0.176 & 0.072 & 0.024 \\
\hline 1987 & 595 & 0.435 & 0.578 & 1.337 & 0.585 & 0.167 & 0.055 & 0.018 \\
\hline 1988 & 639 & 0.447 & 0.580 & 1.486 & 0.564 & 0.193 & 0.062 & 0.023 \\
\hline 1989 & 680 & 0.374 & 0.502 & 1.040 & 0.435 & 0.167 & 0.063 & 0.026 \\
\hline 1990 & 701 & 0.415 & 0.549 & 1.243 & 0.490 & 0.174 & 0.057 & 0.017 \\
\hline 1991 & 712 & 0.516 & 0.621 & 1.797 & 0.696 & 0.235 & 0.074 & 0.023 \\
\hline 1992 & 697 & 0.536 & 0.638 & 2.000 & 0.800 & 0.229 & 0.070 & 0.025 \\
\hline
\end{tabular}

Note: All absolute errors above 2.0 (200 percent) are given a value of 2.0. All observations with negative earnings are deleted.

Analysis of the one-year-ahead forecasts in Table 11 yields qualitatively similar conclusions to those drawn from the current-year forecasts. Elimination of loss companies improves forecast accuracy more in the United States than in Japan, but it does not change the finding that one-year-ahead Japanese forecasts are more accurate than those for the United States. The Japanese forecast advantage, once negatives are removed, appears to be lower at the end of the sample period. In 1992, the $t$-value comparing Japan and the United States is only 1.56 .

The lower prevalence of negative earnings in Japan during the study period suggests that Japanese analysts may benefit from an easier forecasting challenge than their U.S. counterparts in that U.S. earnings streams may be inherently more volatile.

Analysts' versus Random Walk Forecasts. Table 12 compares one-year-ahead and random walk forecasts for Japan and the United States. Only those companies for which both forecasts are available in a given year are 


\section{TABLE 12. Mean Absolute Percentage Errors of Earnings per Share Forecasts for Japanese and United States Firms, Random Walk Forecasts and One-Year-Ahead Analyst Forecasts, 1986-92}

\begin{tabular}{|c|c|c|c|c|c|c|c|}
\hline \multirow[b]{2}{*}{ Year } & \multicolumn{4}{|c|}{ Random Walk Errors } & \multicolumn{3}{|c|}{ Difference in Forecast Error ${ }^{a}$} \\
\hline & $\mathrm{N}$ & Mean & $\begin{array}{l}\text { Standard } \\
\text { Deviation }\end{array}$ & Median & $\begin{array}{c}\text { Mean } \\
\text { Difference }\end{array}$ & $\begin{array}{l}\text { Standard } \\
\text { Deviation }\end{array}$ & $t$ \\
\hline \multicolumn{8}{|c|}{ Japan, Toyo Keizai } \\
\hline 1986 & 584 & 0.449 & 0.577 & 0.208 & -0.031 & 0.407 & -1.86 \\
\hline 1987 & 685 & 0.520 & 0.617 & 0.252 & 0.008 & 0.425 & 0.53 \\
\hline 1988 & 728 & 0.419 & 0.514 & 0.227 & 0.048 & 0.355 & 3.68 \\
\hline 1989 & 771 & 0.378 & 0.440 & 0.220 & 0.070 & 0.324 & 6.05 \\
\hline 1990 & 785 & 0.354 & 0.442 & 0.201 & 0.081 & 0.357 & 6.40 \\
\hline 1991 & 801 & 0.336 & 0.434 & 0.174 & 0.006 & 0.288 & 0.63 \\
\hline 1992 & 680 & 0.534 & 0.624 & 0.249 & -0.016 & 0.374 & -1.16 \\
\hline \multicolumn{8}{|c|}{ U.S., IBES } \\
\hline 1986 & 677 & 0.562 & 0.664 & 0.225 & -0.069 & 0.534 & -3.39 \\
\hline 1987 & 694 & 0.662 & 0.665 & 0.378 & 0.072 & 0.583 & 3.26 \\
\hline 1988 & 720 & 0.654 & 0.679 & 0.365 & 0.089 & 0.600 & 3.98 \\
\hline 1989 & 744 & 0.527 & 0.616 & 0.238 & 0.041 & 0.526 & 2.15 \\
\hline 1990 & 772 & 0.552 & 0.652 & 0.234 & 0.016 & 0.514 & 0.91 \\
\hline 1991 & 812 & 0.646 & 0.675 & 0.324 & -0.000 & 0.526 & -0.00 \\
\hline 1992 & 847 & 0.683 & 0.719 & 0.327 & -0.039 & 0.512 & -2.22 \\
\hline
\end{tabular}

Note: All absolute errors above 2.0 (200 percent) are set equal to 2.0 .

${ }^{a}$ The mean difference between random walk error and analyst forecast error and standard deviation are based on the individual paired differences in forecast errors in which the one-year-ahead forecast error is subtracted from the random walk error. The $t$-statistic tests the hypothesis that the mean difference is zero.

included. As a result, the sample is slightly smaller than in previous tables. ${ }^{19}$ Technically, the random walk forecast is for a slightly shorter horizon than the analysts' next-year forecast. For example, 1985 actual earnings in Japan would typically be announced in May, two months after analysts made their 1985 forecasts of 1986 EPS. A similar delay of earnings announcements exists in the United States. As a result, our comparison biases the results against analysts outperforming a random walk. Unless this bias is different in the two countries, however, it should not affect our conclusions about the relative performance of analysts in the United States and Japan.

The data show that random walk forecast errors are consistently lower in Japan than in the United States. In Japan, the simple random walk forecast results in MAPEs of between 0.336 and 0.534 , depending on the year studied.

\footnotetext{
${ }^{19}$ In both countries, the current-year forecasts are much more accurate than either of these two forecasts, as would be expected given the shorter forecast horizon.
} 
In the United States, the random walk MAPEs range from 0.527 in 1989 to 0.683 in 1992 . The random walk forecast error in Japan is significantly lower than the U.S. random walk error in each year ( $t$-values comparing errors in the two countries are in excess of 3.0 in each year). These differences between the two countries demonstrate that the forecasting challenge for U.S. firms, at least for the period studied, is more difficult than that for Japanese firms. The accuracy of Toyo Keizai forecasts benefits from Japanese companies having, on average, more stable, predictable earnings than U.S firms.

The right-hand portion of Table 12 shows differences between random walk and analysts' forecasts and illustrates that Toyo Keizai outperformed a random walk in 1988 through 1990 but fell short in 1986. For the United States, IBES beat a random walk in 1987 through 1989 but was worse in 1986 and 1992. These results indicate that improvements over a random walk are achievable in both countries, but only some of the time. ${ }^{20}$

The average results for the entire sample period (1986-92) are summarized in Table 13. For the one-year-ahead results, the average improvement in accuracy is very modest in the two countries. This result, in part, reflects the timing advantage of the random walk forecasts noted earlier. Most important for present purposes is the relative performance of Toyo Keizai in Japan and IBES in the United States. During the 1986-92 period, the Toyo Keizai one-year-ahead forecasts provided slightly larger forecast accuracy improvements over a random walk than was the case for the United States, but the statistical support for this finding is weak. In five of the seven years, improvements over a random walk were larger in Japan than in the United States, but in only one of those years (1990) was a $t$-test comparing the improvements significant at the 0.05 level. Furthermore, in 1987, the improvement in the United States was significantly larger than in Japan ( $t$-value of 2.33$)$.

Overall, the evidence in Tables 12 and 13 corroborates the finding that, at least for one-year-ahead forecasts, a large portion of the superior forecast accuracy in Japan may stem from an easier forecasting challenge than prevails in the United States. Although improvements over a random walk are more often larger in Japan than in the United States, the difference in improvement is small.

For shorter horizon forecasts, analysts do better than a random walk in

\footnotetext{
${ }^{20}$ These conclusions differ in some respects from those in our earlier paper (Conroy, Harris, and Park 1993a) for a number of reasons. That work extended only through 1988, and patterns have shifted since then. Also, our use of a maximum error of 200 percent likely damps differences between the random walk and analysts by mitigating the effects of very large errors. Moreover, in this study, we used a slightly different convention for defining years (i.e., we refer to Japanese fiscal years).
} 


\section{TABLE 13. Comparison of Errors Made by Analysts Forecasts and Random Walk Forecasts of Earnings per Share in Japan and the United States, 1986-92}

\begin{tabular}{|c|c|c|}
\hline Calculation & Japan, Toyo Keizai & U.S., IBES \\
\hline \multicolumn{3}{|l|}{ One-year forecasts versus random walk } \\
\hline Mean absolute error from random walk ${ }^{\mathrm{a}}$ & 0.427 & 0.612 \\
\hline Improvement of analysts over random walk ${ }^{b}$ & 0.024 & 0.016 \\
\hline Mean absolute error from analysts & 0.403 & 0.596 \\
\hline Improvement as percent of random walk & $5.6 \%$ & $2.6 \%$ \\
\hline \multicolumn{3}{|l|}{ Current-year forecasts versus random walk } \\
\hline Mean absolute error from random walk ${ }^{\mathrm{a}}$ & 0.427 & 0.612 \\
\hline Improvement of analysts over random walk & 0.263 & 0.369 \\
\hline Mean absolute error from analysts & 0.164 & 0.243 \\
\hline Improvement as percent of random walk error & $61.6 \%$ & $39.7 \%$ \\
\hline \multicolumn{3}{|c|}{$\begin{array}{l}{ }^{2} \text { Average of annual values of mean absolute percentage error (MAPE) over the } 1986-92 \text { period. All abso- } \\
\text { lute errors above } 2.0 \text { (200 percent) are set equal to } 2.0 \text {. }\end{array}$} \\
\hline \multicolumn{3}{|c|}{$\begin{array}{l}\text { b Average of annual values of mean difference between random walk error and analyst forecast errors over } \\
\text { the } 1986-92 \text { period. }\end{array}$} \\
\hline
\end{tabular}

both countries, as would be expected because more information comes out during the year. Table 13 shows substantive MAPE improvements of analysts' current-year forecasts over random walk forecasts in both countries. The Toyo Keizai forecasts show larger improvements than in the United States as a percentage of the random walk error. In Japan, the improvement averages 61.6 percent of the random walk error.

Summary. Industry structure is important in understanding differences in forecast accuracy but cannot explain the superior forecast accuracy of Toyo Keizai forecasts compared with U.S. IBES forecasts. The Japanese forecasts are more accurate in each industry. Negative earnings figures are less common in Japan than in the United States. A simple no-change forecast is more accurate in Japan than in the United States. Controlling for these differences in forecasting challenge goes a long way toward explaining why Toyo Keizai forecasts appear to be more accurate than U.S. IBES forecasts during the sample period. Nevertheless, some evidence suggests that, apart from the different forecasting challenge, Toyo Keizai forecasts are more accurate at least for current-year forecasts.

In the next section, we look at forecasts made by Toyo Keizai and IBES (Japan) for exactly the same firms, which provides an ideal control for differences in underlying forecast variability. 


\section{Toyo Keizai versus Japan IBES Forecasts}

Japanese IBES data, like U.S. IBES data, reflect the average of individual (sell-side) analysts' forecasts, whereas Toyo Keizai forecasts are from a single information provider. This difference may induce different forecasting incentives. In addition, comparison of the Toyo Keizai data with the IBES data should reveal any benefits of consensus in forecasts.

Data Issues. Japanese IBES forecasts are taken from the IBES international data base, which as of December 1993 covers companies in 38 countries outside the United States. Like their U.S. counterparts, these IBES data are provided to a wide array of clients in the investments industry. Conversations with IBES officials revealed that, in the early years (1987 was the first year), the analysts making forecasts for Japanese firms were primarily from Japanese securities houses. By 1993, however, approximately half of the forecasts were from Western firms, which reflects the influx of these firms into the Japanese market.

Our empirical work focuses on those March fiscal year companies for which both IBES and Toyo Keizai forecasts of unconsolidated (parent-only) earnings are available. Because IBES sometimes carries only consolidated figures, the restriction to unconsolidated earnings eliminates approximately one-third of the otherwise-eligible IBES firms. This focus on unconsolidated earnings mirrors industry practice and makes the results comparable to our earlier findings.

Table 14 displays a number of key features of the Japanese IBES data. First, the number of companies increased dramatically during the 1987-90 period as IBES built its international data base. Similarly, the number of analysts in the data base increased steadily. In the first two years of its coverage, the majority of companies had a single-analyst estimate in the IBES mean. By 1992, however, 79 percent of the companies with current-year forecasts had five or more analysts represented in the IBES Japanese data. As Table 14 shows, some analysts provided current-year but not year-ahead forecasts.

Forecast Accuracy. One possible reason for Toyo Keizai's superior forecast accuracy is that it is not a reflection of opinions from sell-side analysts. Table 15 sheds light on this possibility. The Japanese figures reported in Table 15 are only for those companies for which both sets of Japanese forecasts are available, but the results for Toyo Keizai are virtually identical to those in earlier tables in which the data overlap was not required. In each year, mean absolute forecast errors from Toyo Keizai are lower than for Japan IBES. For 
TABLE 14. Number of analysts in IBES Japan Mean Forecast of Earnings

(proportion of sample except for sample size and average number of estimates)

\begin{tabular}{|c|c|c|c|c|c|c|}
\hline Number of Analysts & 1987 & 1988 & 1989 & 1990 & 1991 & 1992 \\
\hline \multicolumn{7}{|c|}{ Current-year forecasts (March forecast of March fiscal year end) } \\
\hline One & 0.58 & 0.57 & 0.02 & 0.01 & 0.00 & 0.00 \\
\hline Two to four & 0.36 & 0.30 & 0.74 & 0.40 & 0.34 & 0.20 \\
\hline Five to seven & 0.05 & 0.10 & 0.20 & 0.48 & 0.50 & 0.49 \\
\hline Eight or more & 0.00 & 0.03 & 0.03 & 0.11 & 0.16 & 0.30 \\
\hline Sample size & 55 & 302 & 403 & 486 & 478 & 500 \\
\hline $\begin{array}{c}\text { Average number } \\
\text { of estimates }\end{array}$ & 2.00 & 2.30 & 1.03 & 5.24 & 5.73 & 6.85 \\
\hline \multicolumn{7}{|c|}{ One-year-ahead forecasts (March forecast of next March) } \\
\hline One & & 0.61 & 0.63 & 0.08 & 0.00 & 0.00 \\
\hline Two to four & & 0.35 & 0.29 & 0.78 & 0.43 & 0.59 \\
\hline Five to seven & & 0.04 & 0.06 & 0.11 & 0.46 & 0.32 \\
\hline Eight or more & & 0.00 & 0.02 & 0.02 & 0.11 & 0.09 \\
\hline Sample size & & 46 & 292 & 400 & 453 & 419 \\
\hline Average number of estimates & & 1.91 & 1.95 & 3.03 & 5.28 & 6.16 \\
\hline
\end{tabular}

Note: Includes only those companies for which we had both Toyo Keizai and IBES Japan forecasts.

current-year forecasts, the difference in accuracy between Toyo Keizai and Japan IBES is significant in each year, and for one-year-ahead forecasts, the difference is significant for each year except 1992. The fourth column shows that the forecast errors in the U.S. IBES data are much higher than those for Japanese IBES. A comparison of the median figures for U.S. and Japanese IBES suggests that a major factor for the better accuracy in Japan is the avoidance of very large errors, which drive up the mean.

Table 15 illustrates a key result of this study. Even controlling for any differences in the underlying companies being forecast, Toyo Keizai does better than the average of sell-side analysts in predicting future earnings. Toyo Keizai has an advantage over Japanese IBES even when forecasting the same companies at the same time. Looking across the entire sample period, the difference between Toyo Keizai and Japan IBES current-year errors is an impressive 12.37 standard errors from zero. For one-year-ahead forecasts, the comparable $t$-value is 6.53 .

An ancillary of this conclusion is that Toyo Keizai's advantages outweigh any consensus benefits embedded in IBES. In Table 16, companies are classified according to the number of analysts going into the Japanese IBES mean. The data are for the 1990-92 period, when IBES data contained more analysts' forecasts. Three conclusions stand out. First, more analysts appear 
TABLE 15. Mean and Median Absolute Percentage Forecast Errors of Earnings per Share for Japanese and U.S. Companies, 1987-92

\begin{tabular}{|c|c|c|c|c|c|c|c|}
\hline \multirow[b]{2}{*}{ Year } & \multicolumn{4}{|c|}{ Mean Values } & \multicolumn{3}{|c|}{ Median Values } \\
\hline & $\begin{array}{c}\text { Toyo } \\
\text { Keizai }^{\mathrm{a}}\end{array}$ & $\begin{array}{l}\text { Japan } \\
\text { IBES }^{a}\end{array}$ & $\begin{array}{c}\text { Difference } \\
t \text {-value }\end{array}$ & $\begin{array}{l}\text { U.S. } \\
\text { IBES }^{\mathrm{c}}\end{array}$ & $\begin{array}{c}\text { Toyo } \\
\text { Keizai }^{a}\end{array}$ & $\begin{array}{l}\text { Japan } \\
\text { IBES }^{\mathrm{a}}\end{array}$ & $\begin{array}{l}\text { U.S. } \\
\text { IBES }^{\mathrm{c}}\end{array}$ \\
\hline \multicolumn{8}{|c|}{ Current-year forecasts } \\
\hline 1987 & 0.180 & 0.246 & 1.92 & 0.378 & 0.054 & 0.105 & 0.089 \\
\hline 1988 & 0.147 & 0.208 & 4.42 & 0.356 & 0.074 & 0.113 & 0.094 \\
\hline 1989 & 0.117 & 0.182 & 6.27 & 0.327 & 0.065 & 0.096 & 0.075 \\
\hline 1990 & 0.105 & 0.161 & 6.49 & 0.332 & 0.051 & 0.075 & 0.079 \\
\hline 1991 & 0.150 & 0.197 & 4.25 & 0.391 & 0.066 & 0.094 & 0.097 \\
\hline 1992 & 0.208 & 0.298 & 6.36 & 0.431 & 0.083 & 0.121 & 0.120 \\
\hline All years ${ }^{\mathrm{d}}$ & 0.147 & 0.211 & 12.37 & 0.354 & 0.066 & 0.098 & 0.084 \\
\hline \multicolumn{8}{|c|}{ One-year-ahead forecasts } \\
\hline 1988 & 0.305 & 0.392 & 2.43 & 0.565 & 0.125 & 0.222 & 0.252 \\
\hline 1989 & 0.303 & 0.341 & 3.00 & 0.486 & 0.190 & 0.215 & 0.203 \\
\hline 1990 & 0.278 & 0.322 & 4.40 & 0.535 & 0.172 & 0.204 & 0.209 \\
\hline 1991 & 0.343 & 0.384 & 4.94 & 0.646 & 0.175 & 0.206 & 0.320 \\
\hline 1992 & 0.553 & 0.565 & 0.92 & 0.721 & 0.268 & 0.290 & 0.381 \\
\hline All years ${ }^{d}$ & 0.373 & 0.407 & 6.53 & 0.590 & 0.198 & 0.227 & 0.250 \\
\hline
\end{tabular}

aSample includes Japanese companies for which both Toyo Keizai and Japan IBES forecasts are available. All errors greater than 2.0 (less than -2.0$)$ are set equal to $2.0(-2.0)$.

${ }^{\mathrm{b}}$ Difference $t$-values test the hypothesis that Toyo Keizai and Japanese IBES means are equal and is based on the individual paired differences in forecast errors in which the Toyo Keizai forecast error is subtracted from the Japan IBES forecast error.

${ }^{c}$ Sample includes U.S. companies with IBES forecasts.

${ }^{\mathrm{d} C a l c u l a t e d ~ o v e r ~ a l l ~ o b s e r v a t i o n s ~ o v e r ~ t h e ~ e n t i r e ~ s a m p l e ~ p e r i o d . ~}$

to follow companies that are easier to forecast. Although MAPEs from IBES drop as the number of analysts increases, so do the MAPEs from Toyo Keizai, which has no consensus benefits of averaging. Second, Toyo Keizai forecasts are more accurate in every category of analyst following. Third, although for current-year forecasts Toyo Keizai's forecast advantage appears to decline as the number of analysts in IBES increases, this pattern does not hold for one-year-ahead forecasts. Thus, Table 16 provides no strong evidence of consensus benefits embedded in Japanese IBES.

Forecast Bias. U.S. IBES forecasts have been shown to display persistent optimism. In earlier portions of this work, we show that the mean signed U.S. IBES forecast errors are positive in each year; current-year MSPEs average 0.260 for the sample period, and one-year-ahead MSPEs are even higher (see Tables 5 and 6 ). This pattern is consistent with reward structures 
TABLE 16. Forecast Accuracy in Japan and the Number of Analysts Following a Stock, 1990-92

(mean absolute percentage error)

\begin{tabular}{llccc}
\hline & \multicolumn{4}{c}{ Number of Analysts in IBES } \\
\cline { 2 - 5 } Forecast & One & Two to Four & Five to Seven & Eight or More \\
\hline Current-year forecasts & 0.887 & 0.273 & 0.211 & 0.146 \\
Japan IBES & $\underline{0.277}$ & $\underline{0.208}$ & $\underline{0.142}$ & $\underline{0.100}$ \\
Toyo Keizai & 0.610 & 0.065 & 0.069 & 0.046 \\
Difference & 1.42 & 4.83 & 7.06 & 5.55 \\
$t$-value & & & & \\
& & & & \\
One-year-ahead forecasts & 0.446 & 0.440 & 0.417 & 0.315 \\
Japan IBES & 0.402 & 0.414 & 0.375 & 0.282 \\
Toyo Keizai & 0.044 & 0.026 & 0.042 & 0.033 \\
Difference & 3.08 & 3.22 & 4.23 & 2.03 \\
$t$-value & &
\end{tabular}

${ }^{a}$ The number of analysts refers to the number of analysts in the IBES mean forecast. In all cases, a Toyo Keizai forecast for a company is a single estimate not a mean across analysts. All absolute errors above 2.0 (200 percent) are set equal to 2.0 .

bThe $t$-values test the hypothesis that the mean difference between Toyo Keizai and Japan IBES is zero and is based on the individual paired differences in forecast errors in which the Toyo Keizai forecast error is subtracted from the Japan IBES forecast error.

that might make sell-side analysts more prone to bullish forecasts. In contrast, Japanese Toyo Keizai forecasts do not exhibit such a positive bias.

Table 17 compares biases in Japan for IBES and Toyo Keizai. If a sell-side effect is at the root of overoptimism, the sell-side IBES Japan data should have a positive bias. Compared with the optimism in the United States, the Japanese IBES data show a much smaller positive bias. Positive bias is present, however. For current-year MSPEs, the Japanese IBES figure is positive in four of the six years and is significantly so in the last three years (1990-92). In addition, the Japanese IBES current-year MSPEs are always above the Toyo Keizai MSPEs and significantly so in four years. For the entire period, the difference between errors from Japan IBES and Toyo Keizai averages 0.054 , which is significantly different from zero $(t=7.47)$. The low median values for current-year MSPEs show the prevalence of large forecast errors, which drive up the mean in Japanese IBES data. The one-year-ahead figures in Table 17 show Japanese IBES to be more optimistic than Toyo Keizai and significantly so for the entire sample period $(t=5.48)$.

On balance, IBES forecasts in Japan appear to have a positive bias and to be more optimistic than Toyo Keizai forecasts for the same firms. This bias, however, is much smaller than that seen in U.S. IBES data during the same time period. These findings are consistent with a sell-side effect, but it is less 
TABLE 17. Mean and Median Signed Percentage Forecast Errors of Earnings per Share for Japanese Companies, 1987-92 ( $t$-values in parenthesis)

\begin{tabular}{|c|c|c|c|c|c|}
\hline \multirow[b]{2}{*}{ Year } & \multicolumn{3}{|c|}{ Mean Values } & \multicolumn{2}{|c|}{ Median Values } \\
\hline & Toyo Keizai & Japan IBES & $\begin{array}{c}\text { Mean } \\
\text { Difference }^{\mathrm{a}}\end{array}$ & Toyo Keizai & Japan IBES \\
\hline \multicolumn{6}{|c|}{ Current-year forecasts } \\
\hline 1987 & $\begin{array}{r}-0.043 \\
(-0.73)\end{array}$ & $\begin{array}{c}0.081 \\
(1.23)\end{array}$ & $\begin{array}{c}0.124 \\
(1.53)\end{array}$ & -0.022 & -0.018 \\
\hline 1988 & $\begin{array}{l}-0.047 \\
(-2.91)\end{array}$ & $\begin{array}{l}-0.001 \\
(-0.05)\end{array}$ & $\begin{array}{c}0.046 \\
(2.30)\end{array}$ & -0.045 & -0.039 \\
\hline 1989 & $\begin{array}{l}-0.037 \\
(-3.08)\end{array}$ & $\begin{array}{r}0.017 \\
(-1.04)\end{array}$ & $\begin{array}{c}0.02 \\
(1.21)\end{array}$ & -0.033 & -0.039 \\
\hline 1990 & $\begin{array}{l}-0.008 \\
(-0.85)\end{array}$ & $\begin{array}{c}0.033 \\
(2.29)\end{array}$ & $\begin{array}{c}0.041 \\
(3.13)\end{array}$ & -0.010 & 0.001 \\
\hline 1991 & $\begin{array}{c}0.000 \\
(0.000)\end{array}$ & $\begin{array}{c}0.042 \\
(2.43)\end{array}$ & $\begin{array}{c}0.042 \\
(3.27)\end{array}$ & -0.020 & -0.006 \\
\hline 1992 & $\begin{array}{c}0.113 \\
(6.43)\end{array}$ & $\begin{array}{c}0.218 \\
(9.97)\end{array}$ & $\begin{array}{c}0.105 \\
(5.70)\end{array}$ & 0.027 & 0.073 \\
\hline All years ${ }^{b}$ & $\begin{array}{r}0.009 \\
(1.43)\end{array}$ & $\begin{array}{r}0.063 \\
(7.60)\end{array}$ & $\begin{array}{r}0.054 \\
(7.47)\end{array}$ & -0.013 & -0.001 \\
\hline \multicolumn{6}{|c|}{ One-year-ahead forecasts } \\
\hline 1988 & $\begin{array}{c}-0.104 \\
(-1.23)\end{array}$ & $\begin{array}{c}0.101 \\
(1.07)\end{array}$ & $\begin{array}{c}0.205 \\
(2.24)\end{array}$ & -0.065 & 0.029 \\
\hline 1989 & $\begin{array}{l}-0.062 \\
(-2.25)\end{array}$ & $\begin{array}{l}-0.037 \\
(-1.28)\end{array}$ & $\begin{array}{c}0.024 \\
(1.36)\end{array}$ & -0.122 & -0.103 \\
\hline 1990 & $\begin{array}{l}-0.004 \\
(-0.18)\end{array}$ & $\begin{array}{c}0.034 \\
(1.38)\end{array}$ & $\begin{array}{c}0.038 \\
(3.38)\end{array}$ & -0.047 & -0.024 \\
\hline 1991 & $\begin{array}{c}0.129 \\
(5.08)\end{array}$ & $\begin{array}{c}0.180 \\
(6.59)\end{array}$ & $\begin{array}{r}0.051 \\
(5.54)\end{array}$ & -0.004 & 0.057 \\
\hline 1992 & $\begin{array}{c}0.379 \\
(10.44)\end{array}$ & $\begin{array}{r}0.388 \\
(10.79)\end{array}$ & $\begin{array}{c}0.009 \\
(0.67)\end{array}$ & 0.152 & 0.173 \\
\hline All years ${ }^{b}$ & $\begin{array}{r}0.119 \\
(8.07) \\
\end{array}$ & $\begin{array}{r}0.155 \\
(10.15) \\
\end{array}$ & $\begin{array}{r}0.036 \\
(5.48) \\
\end{array}$ & -0.014 & 0.019 \\
\hline
\end{tabular}

Note: All errors greater than 2.0 (less than -2.0$)$ are set equal to $2.0(-2.0)$.

The mean difference and its $t$-value are based on the individual paired differences in which the Toyo Keizai forecast error is subtracted from the Japan IBES forecast error.

${ }^{\mathrm{b}}$ Calculated over all observations over the entire sample period.

pronounced in Japan than in the United States.

Timeliness of Forecasts and Japan IBES Updates. Of particular concern in this study is that forecasts entering the IBES mean may be stale, because individual analysts follow different revision and dissemination cycles. For instance, O'Brien (1988) found that the average individual forecast in U.S. IBES is 34 days old and showed that more-current individual forecasts are 
more accurate than older ones.

Our comparison of Toyo Keizai and Japanese IBES forecasts has March forecasts, which reflect Toyo Keizai's end-of-year updates as published in the Japan Company Handbook. Rather than a quarterly revision cycle, such as that of Toyo Keizai, IBES provides monthly mean figures reflecting the current forecasts of the participating analysts. Because the individual analysts adopt their own revision and dissemination policies, some of the forecasts in IBES may not have been updated in the previous few months.

To examine any systematic revision practices, we looked at Japanese IBES forecasts beginning in September and continuing through May for currentyear forecasts and through June for one-year-ahead forecasts. This sequence of monthly forecasts reveals a clear pattern of revisions with changes concentrated at the end of the calendar year and again just after the end of the fiscal year. Figure 5 displays forecast errors from using the IBES forecast in alternative months to predict current-year earnings. For instance, the figure for December is the difference between the MAPE using the forecast available in December and the MAPE using the forecast available in March. Because actual earnings do not change across the forecast months, the movement in Figure 5 is solely attributable to forecast revisions. Two clear patterns are evident. First, the forecasts become more accurate the shorter the forecast horizon. Second, the main revisions in IBES occur in December/January and April, as revealed by the downward turns in those months. This concentrated revision pattern is born out by the number of revised forecasts reported by

\section{FIGURE 5. Current-Year Absolute Forecast Error Relative to March Error Using Japanese IBES, Average 1990-92}

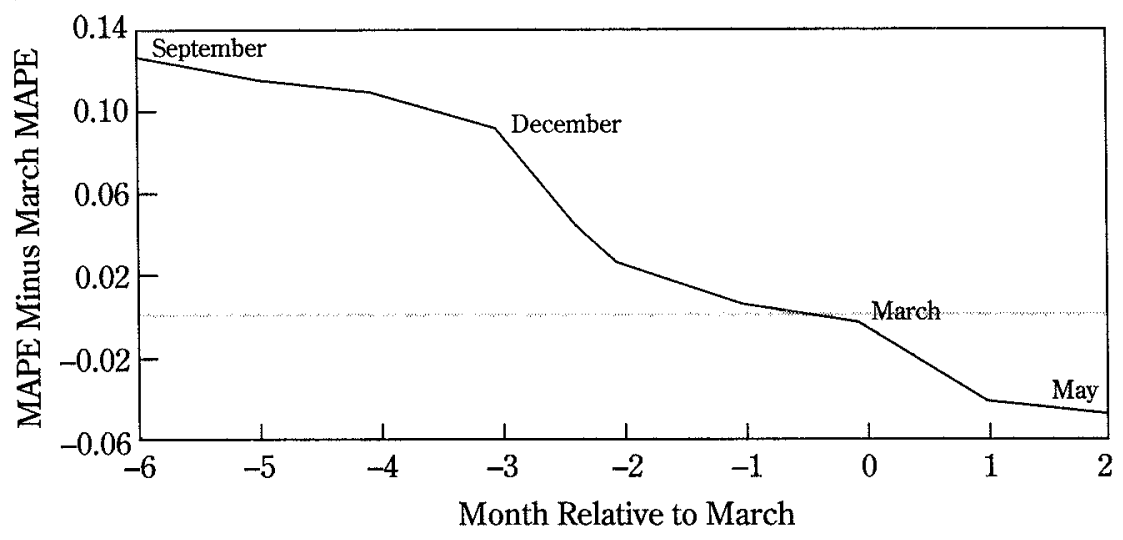


IBES. The number of revisions peaks at the end of the calendar year and again in April. The same patterns in MAPEs and revisions also appear in the year-ahead forecasts.

The evidence in Figure 5 suggests that part of the forecasting superiority of Toyo Keizai over Japanese IBES is a timing advantage. As of the date that Toyo Keizai forecasts become public, the IBES mean still contains old estimates that are subsequently revised in April and later months. It is plausible to assume that, in fact, many analysts use the Toyo Keizai forecasts as part of the information they incorporate into their April revisions.

This timing advantage of Toyo Keizai over IBES might not be as pronounced if one had access to real-time IBES data rather than using the monthly figures available to us for research. Nevertheless, given differences in analysts' revision cycles and delays in reporting numbers to IBES, an average such as the IBES mean will always include some stale forecasts. Furthermore, even allowing for a one-month lag (e.g., pitting April IBES numbers against March Toyo Keizai figures), IBES errors are larger than those for Toyo Keizai. Why stale forecasts should lead to more optimism (as opposed to less accuracy) in IBES as compared to Toyo Keizai is not clear.

On balance, the vintage of individual forecasts in the IBES average is certainly important in making inferences about individual forecasters from results based on using an IBES mean. Although further research on the issue is warranted, our analysis suggests that stale forecasts are not sufficient to explain the differences between Toyo Keizai and IBES forecasts. Additionally, the presence of stale forecasts is an inherent disadvantage of adopting a simple average as an industry benchmark for market expectations.

\section{Summary and Conclusions}

As investors continue to look across national boundaries, knowledge of institutional settings and practices in other countries becomes increasingly important for sound equity selection. We provide a comprehensive comparison of the properties of financial analysts' earnings forecasts in the world's two largest equity markets, Japan and the United States.

The Japanese system for calculating, reporting, and forecasting earnings has unique features. The industry standard for earnings forecasts in Japan is the Toyo Keizai Profit Forecast. These Toyo Keizai forecasts are the benchmark against which an analyst's individual forecast is likely to be gauged and the baseline for assessing whether actual earnings depart from expectations. Toyo Keizai forecasts benefit from direct input from Japanese management through questionnaires and are produced by an information provider that is not involved in making stock recommendations. Furthermore, the Japanese 
system provides for public management forecasts of earnings figures. These features contribute to a Japanese industry standard for earnings forecasts that is quite different from sources such as IBES in the United States, which are based on a collection of forecasts from individual sell-side analysts. These differences include differences in information, in incentive structures, and in the number of forecasters following a company, all of which may affect earnings forecasts.

In a comparison of forecast accuracy and bias for Toyo Keizai earnings forecasts over the 1985-92 period with IBES forecasts in the United States, we found that analysts' earnings forecasts in Japan (made by Toyo Keizai) are consistently more accurate than forecasts in the United States (as measured by $I B E S)$. This superior accuracy holds for forecasts of the year about to end, as well as the next fiscal year. The better accuracy in Japan is to considerable measure driven by avoidance of very large forecast errors found for some U.S. companies.

Our results show that the difference in forecast accuracy between the United States and Japan cannot be ascribed to differences in industrial composition of the two equity markets. Even though industries do make a difference in forecast accuracy, Japanese forecasts are more accurate in each industry studied.

One explanation of the superior forecast accuracy in Japan is that Japanese analysts face an easier forecasting challenge. Our results show that a simple no-change (random walk) forecast in Japan is more accurate than the same type of forecast in the United States. In addition, we found that negative earnings have been less prevalent among Japanese than U.S. companies. Negative earnings are a major source of forecast error, because analysts seldom forecast such downturns. As a result, differences in forecasting challenge go a long way toward explaining the different forecast accuracy in the two countries. Even when companies with negative earnings are eliminated from the sample, however, U.S. forecasts are less accurate than those in Japan.

During the study period, Japanese analysts (Toyo Keizai) do not exhibit the overoptimism found in U.S. IBES forecasts. This relative absence of rose-colored glasses in Japan may reflect the predictions of an information provider that is not engaged in making recommendations for stock selection, in contrast to the sell-side analysts who make the IBES forecasts in the United States.

Toyo Keizai forecasts have been more accurate and less optimistic than the relatively new IBES data in Japan. These forecast differences suggest that differences between an information provider and sell-side analysts in IBES may play an important role in understanding published forecasts. Some evidence indicates, however, that this differential may in part reflect stale forecasts contained in the IBES data. 
Overall, our work shows key differences in benchmarks for earnings forecasts between Japan and the United States. Understanding of such differences and the resultant nature of earnings forecasts provides important background for sound navigation through Japanese equity markets. 


\section{Appendix A. Fiscal Years in Japan and the United States}

The bulk of Japanese companies have a fiscal year ending March 31, whereas the most common U.S. fiscal year end is December 31. Table A-1 shows the distribution of fiscal years in the two countries. Because of differing fiscal years, the timing of information release is different in the two countries. For instance, Japanese companies would announce 1990 fiscal year results about May 1990. U.S. fiscal year 1990 results would be announced in early 1991. The result is approximately a nine-month difference in the release of 1990 fiscal year data in the two countries. To provide for a shorter time difference, we used the convention of comparing the 1990 Japanese fiscal year to the 1989

TABLE A-1. Fiscal Year End Months in Japan and the United States (percentage of total companies)

\begin{tabular}{|c|c|c|c|c|}
\hline \multirow[b]{2}{*}{ Month } & \multicolumn{2}{|c|}{$\begin{array}{l}\text { Tokyo Stock Exchange } \\
\text { 1st Section }\end{array}$} & \multicolumn{2}{|c|}{ New York Stock Exchange } \\
\hline & 1985 & 1990 & 1985 & 1990 \\
\hline January & $2.2 \%$ & $1.3 \%$ & $4.4 \%$ & $4.1 \%$ \\
\hline February & 5.6 & 5.1 & 1.7 & 1.5 \\
\hline March & 54.9 & 78.2 & 4.0 & 4.1 \\
\hline April & 4.8 & 0.8 & 2.0 & 1.6 \\
\hline May & 3.8 & 1.0 & 1.8 & 1.6 \\
\hline June & 1.3 & 0.3 & 7.7 & 7.2 \\
\hline July & 1.2 & 0.1 & 1.8 & 2.0 \\
\hline August & 1.1 & 0.3 & 1.8 & 1.8 \\
\hline September & 7.0 & 2.2 & 5.8 & 5.7 \\
\hline October & 2.6 & 0.8 & 2.9 & 2.5 \\
\hline November & 6.1 & 2.3 & 2.0 & 1.5 \\
\hline December & 9.5 & 7.6 & 64.0 & 66.3 \\
\hline $\begin{array}{l}\text { Number of } \\
\text { companies }\end{array}$ & 1,038 & 1,063 & 1,415 & 1,569 \\
\hline
\end{tabular}


U.S. fiscal year, which produces a difference of only three months. Also, we adopted the convention of referring to all years by the relevant Japanese fiscal year. For instance, "1990" would refer to the Japanese 1990 fiscal year ending March 1990 and the U.S. 1989 fiscal year ending December 1989. The convention thus refers to the 1990 calendar year when year-end results actually become known. 


\section{Appendix B. The Japan Company Handbook}

The Japan Company Handbook (JCH) is published quarterly by Toyo Keizai, Inc. We use the JCH-First Section, which covers all Japanese companies in the first sections of the Tokyo, Osaka, and Nagoya Stock exchanges and is published in January, April, July, and October. The Summer 1992 JCH-First Section, for example, covered 1,294 companies as of April 2, 1992. In our analysis of forecast accuracy, we restrict our focus to Tokyo Stock Exchange First Section firms.

Although the first-quarter $\mathrm{JCH}$ is published at the beginning of April, the data are available earlier in the Japanese language version (Kaisha Shikiho) that comes out in March. As a result, waiting for the English language translation would put a user at a disadvantage for some purposes. The April publication date would continue to predate announcements of actual earnings, however.

Exhibit B-1 shows a sample page of information for Hitachi from the Summer 1992 JCH-First Section. ${ }^{1}$. The different blocks of information are coded A through $\mathrm{N}$. In the front of the handbook, the types of information in each block are discussed. The blocks of information are:
A. Corporate name and order of listing
B. Characteristics (industry, history, strategy, etc.)
C. Outlook
D. Income data
E. Sales breakdown
F. Stock prices
G. Stock price chart
H. Stocks (par value, shares outstanding, number of shareholders, etc.)
I. Finance

\footnotetext{
${ }^{1}$ This figure and the subsequent discussion draws heavily on the material at the beginning of the Summer 1992 JCH-First Section.
} 
EXHIBIT B-1. Sample Page From the Japan Company Handbook

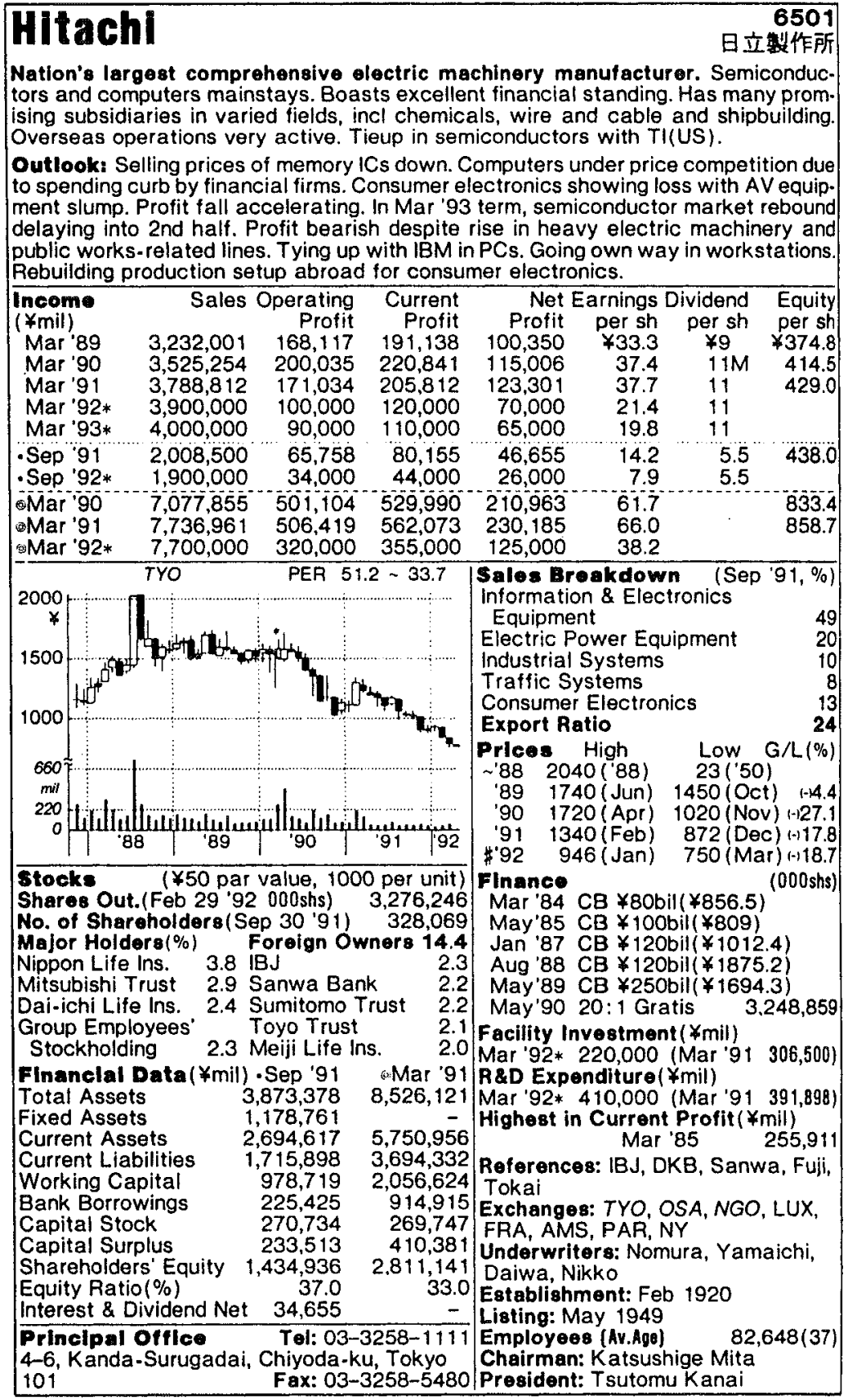

Source: Summer 1992 Japan Company Handbook published by Toyo Keizai. 
J. Financial data

K. Investment and other (e.g., facility investment, R\&D)

L. References and other

M. Date of Establishment and other

N. Principal offices

The specific forecasts we use in our analysis are from Section D-Income Data. From Exhibit B-1, the starred rows in Block D for March 1992 and March 1993 give Toyo Keizai's forecasts for the fiscal years ending in these respective months. Specifically, the forecast for 1992 EPS (current year) is 21.4 yen and, for 1993 (one year ahead), 19.8 yen. Note that, as of the publication of the Handbook, no announcement has been made of 1992 EPS. These EPS figures are for unconsolidated earnings. 


\section{Appendix C. Industry Definitions}

To segment our sample companies into industries, we use the seven sectors from Roll (1992), which are defined by the FT Actuaries/Goldman Sachs International Equity Indexes. Exhibit C-1 lists the composition of the sectors and is adapted directly from Roll (1992, pp. 39-41). The groupings listed below each sector heading are at the three-digit industry level in the FT/Goldman scheme. To assign Japanese companies to the sectors, we matched the industry codings from the Toyo Keizai Japan Company Handbook to those in Exhibit C-1. In the United States, we used a similar matching procedure based on Compustat industry codes. Although the industry groups (roughly comparable to the three- or four-digit SIC level) differ somewhat among the three different sources, partitioning into the seven major sectors was relatively straightforward.

\section{EXHIBIT C-1. Major Industrial Sectors and Constituent Industries}

Financial, insurance, and real estate

Commercial, banks \& other banks

Financial institutions

Financial services

Investment trusts

Investment companies

Insurance

Life

Agents \& brokers

Multiline

Property \& casualty

Real estate

Diversified holding companies

\section{Energy}

Oil

Internationals

Crude producers

Petroleum products \& refineries

Non-oil energy sources

Energy equipment \& services

\section{Utilities}

Electric utilities \& water works supply
Natural gas utilities

Telephone companies

Transportation and storage

Air transport carriers

Freight forwarders

Sea transport

Rail \& road transport

Storage, warehousing \& supporting transport

\section{Consumer goods and services}

Automobiles

Household durables \& appliances

Diversified consumer goods \& services

Apparel

Textile products

Footwear

Beverages

Brewers

Distillers

Soft drinks

Tobacco manufacturers

Health care

Cosmetics 
EXHIBIT C-1. Major Industrial Sectors and Constituent Industries (continued)

\author{
Drugs \\ Hospital supply \& management \\ Food processors \\ Food-sugar \& confectionery \\ Soaps \\ Agriculture \& fishing \\ Entertainment \& leisure time \\ Toys \\ Photography \\ Restaurants \& hotels \\ Printing \\ Publishing \\ Publishing-newspapers \\ Broadcasting media \\ Advertising \\ Business services \\ Computer software \& services \\ Retail \\ Department stores \\ General merchandise \\ Grocery chains \\ Drug chains \\ Miscellaneous \& specialty \\ Wholesale \\ Durables \\ Nondurables \\ Capital goods \\ Aerospace \& defense \\ Defense electronics \\ Aircraft manufacturers \\ Computers \\ Communications equipment \\ Office equipment
}

\author{
Electrical equipment \\ Electronics \\ Instrumentation \& control equipment \\ Engineering services \& pollution control \\ Machine tools \\ Machinery \\ Construction \\ Farm equipment \\ Industrial \& specialty \\ Auto Parts \\ Original equipment \\ Aftermarket \\ Auto trucks \& parts \\ Tire \& rubber goods \\ Diversified industrials \\ Heavy engineering \& shipbuilding \\ Basic industries \\ Building materials \\ Ceramics \\ Construction \\ Homebuilding \\ Chemicals, fibers, paints \& gases \\ Chemicals (diversified) \\ Fertilizers \\ Mining \& extractive industries \\ Metal ore mining \\ Iron \& steel \\ Nonferrous metals \\ Precious metals \& minerals \\ Forestry products \\ Paper \& paper products \\ Fabricated metal products \\ Containers
}

Source: These sectors and industry groupings are taken from Roll (1992), who takes them from the FT Actuaries/Goldman Sachs International Equity Indexes. 


\section{References}

Abarbanell, Jeffrey, and Victor Bernard. 1992. "Tests of Analysts' Overreaction/Underreaction to Earnings Information as an Explanation for Anomalous Stock Price Behavior." Journal of Finance, vol. 47, no. 3 (July):1181-206.

Abarbanell, Jeffrey S., William N. Lanen, and Robert E. Verrecchia. 1993. "Analysts' Forecasts as Proxies for Investor Beliefs in Empirical Research." Working Paper, University of Michigan.

Aoki, Masahiko. 1990. "Toward an Economic Model of the Japanese Firm." Journal of Economic Literature, vol.28, no. 1 (March):1-27.

Baginski, S.P., and J.M. Hassell. 1990. "The Market Interpretation of Management Forecasts as a Predictor of Subsequent Financial Analyst Forecast Revision." Accounting Review, vol. 65, no. 1 (January):175-90.

Ball, Ray, and Philip Brown. 1968. "An Empirical Evaluation of Accounting Numbers." Journal of Accounting Research, vol.6, no. 2:159-78.

Bartley, J.W., and A.B. Cameron. 1991. "Long-Run Earnings Forecasts by Managers and Financial Analysts." Journal of Business Finance and Accounting, vol. 18, no. 1 (January):21-41.

Bavishi, Vinod B., and Stephen E. Bepler. 1990. "Researching Non-U.S. Companies." In Investing Worldwide. Charlottesville, Va.: Association for Investment Management and Research.

Beaver, William H. 1968. "The Information Content of Annual Earnings Announcements." Empirical Research in Accounting: Selected Studies, supplement to Journal of Accounting Research, vol. 1:67-92.

Boebel, Richard B. 1991. "The Information Content of Financial Analysts' Forecasts: ShortTerm vs. Long-Term.” Dissertation, University of North Carolina, Chapel Hill.

Brown, Lawrence D. 1993. "Earnings Forecasting Research: Its Implications For Capital Markets Research." International Journal of Forecasting, vol. 9, no. 3 (November):295-320.

Brown, Lawrence D., P.G. Foster, and E. Noreen. 1985. "Security Analyst Multi-year Forecasts and the Capital Market." Studies in Accounting Research, No. 21.

Brown, Stephen J., and Jerold B. Warner. 1985. "Using Daily Stock Returns: The Case of Event Studies." Journal of Financial Economics, vol. 14, no. 1 (March):3-31.

Chan, Louis K.C., Yasuhi Hammao, and Josef Lakonishok. 1991. "Fundamentals and Stock Returns in Japan." Journal of Finance, vol. 46, no. 5 (December):1739-64.

. 1993. “Can Fundamentals Predict Japanese Stock Returns?" Financial Analysts Journal, vol. 49, no. 4 (July/August):63-69.

Choi, Frederick D.S., and Richard M. Levich. 1991. "International Accounting Diversity: Does it Affect Market Participants?” Financial Analysts Joumal, vol. 4 (July/August):73-82.

Conrad, Jennifer, and Gautam Kaul. 1993. "Long-Term Market Overreaction or Biases in Computed Returns?" Journal of Finance, vol. 48, no. 1 (March):39-63. 
Conroy, Robert, and Kenneth Eades. 1993. "Dividend Policy and the Impact of Gratis (Bonus) Issues in Japan." Working Paper, University of Virginia.

Conroy, Robert, and Robert S. Harris. 1987. "Consensus Forecasts of Corporate Earnings: Analysts' Forecasts and Time Series Methods." Management Science, vol. 33, no. 6 (Spring):725-38.

Conroy, Robert, Robert S. Harris, and Young Park. 1993a. 'Published Analysts' Earnings Forecasts in Japan: How Accurate Are They?" Pacific-Basin Finance Journal, vol. 1 (May):12737.

1993b. "Earnings Forecasts and Stock Prices in Japan: The Role of Analyst and Management Predictions." Working Paper, Darden School, University of Virginia.

Darrough, Masako N., and Trevor S. Harris. 1991. "Do Management Forecasts of Earnings Affect Stock Prices in Japan?" In Japanese Financial Market Research. W.T. Ziemba, W. Bailey, and Y. Hamao (eds.). Amsterdam: North-Holland:197-229.

DeBondt, Werner F., and Richard H. Thaler. 1990. "Do Security Analysts Overreact?" American Economic Review, vol. 80, no. 2 (May):52-57.

Dimson, Elroy, and Paul Marsh. 1986. "Event Study Methodologies and the Size Effect: The Case of UK Press Recommendations." Journal of Financial Economics, vol. 17, no. 1:113-42.

Elton, E.J., and M.J. Gruber. 1989. "Analysts' Expectations and Japanese Stock Prices." In Japanese Capital Markets, (eds.) E.J. Elton and M.J. Gruber. New York: Harper and Row.

Elton, E.J., M.J. Gruber, and M. Gultekin. 1981. "Expectations and Share Prices." Management Science, vol. 27, no. 9 (September):975-87:

French, Kenneth, and J.M. Poterba. 1991. "Were Japanese Stock Prices Too High?” Journal of Financial Economics, vol. 29, no. 2:337-63.

Givoly, D., and J. Lakonishok. 1984. "Properties of Analysts' Forecast of Earnings: A Review and Analysis of the Research." Journal of Accounting Literature, vol. 3 (Spring):117-52.

Haskins, Mark E., Kenneth R. Ferris, and Thomas I. Selling. Forthcoming. "International Financial Reporting and Analysis: A Contextual Emphasis." Burr Ridge, Ill.: Richard D. Irwin, Inc.

Hassell, J.M., R.H. Jennings, and D.J. Lasser. 1988. "Management Earnings Forecasts: Their Usefulness as a Source of Firm-Specific Information to Security Analysts." Journal of Financial Research, vol. 11, no. 4 (Winter):303-19.

IBES. 1992. "Annotated Bibliography of Earnings Expectations Research," (4th ed). IBES, Inc., 345 Hudson St., New York, N.Y.

Ishizuka, Hiroshi. 1978. "The Effectiveness of Accounting Information in Capital Market (Pilot Test): Does Accounting Information Affect Investor Behavior?" Kigyo-Kaikei (Business Accounting), vol. 30:5-12. (In Japanese).

Ito, Kunio. 1990. "The Relative and Incremental Information Content of Consolidated Earnings Data." Hitotsubashi Journal of Commerce and Management, vol. 25:47-74.

Japan Securities Research Institute. 1992. Securities Market in Japan 1992. Tokyo: Japan Securities Research Institute. 
Kahneman, Daniel, and Amos Tversky. 1973. "On the Psychology of Prediction." Psychological Review, vol. 80, no. 4:237-51.

Kaplan, Steven N. 1992. "Top Executive Rewards and Firm Performance: A Comparison of Japan and the U.S." Working Paper, National Bureau of Economic Research, Cambridge, Mass.

Kobayashi, Shinichi. 1975. "Evaluation of the Efficiency of the Stock Market." Zaikai (Economic World Observer), vol. 40:22-29. (In Japanese)

Kubota, Keiichi. 1980. "Information Content of Accounting Numbers: Evidence on Tokyo Stock Exchange Firms.” International Journal of Accounting, vol. 15:61-76.

Mattione, Richard P. 1992. "A Capital Cost Disadvantage For Japan?” Morgan Guaranty Trust Company (April 6):1-24.

McNichols, M. 1989. "Evidence of Informational Asymmetries from Management Earnings Forecasts and Stock Returns." Accounting Review, vol. 64, no. 1 (January):1-27.

Morse, Dale. 1981. "Price and Trading Volume Reaction Surrounding Earnings Announcements: A Closer Examination." Journal of Accounting Research, vol. 19, no. 2:374-83.

O'Brien, Patricia. 1988. "Analysts' Forecasts as Earnings Expectations." Journal of Accounting and Economics, vol. 10, no. 1:53-83.

Ohtsuki, Muneharu. 1981. "The Effectiveness of Accounting Information in Capital Market: Information Effect of Accounting Announcements." Kigyo-Kaikei (Business Accounting), vol. 33:374-83. (In Japanese)

Patz, D.H. 1989. “UK Analysts' Earnings Forecasts.” Accounting \& Business Research, vol. 19, no. 75 (Summer):267-75.

Philbrick, Donna, and William Ricks. 1991. "Using Value Line and IBES Analyst Forecasts in Accounting Research." Journal of Accounting Research, vol. 29, no. 2 (Autumn):397-417.

Poterba, James M. 1991. "Comparing the Cost of Capital in the United States and Japan: A Survey of Methods." Quarterly Review, Federal Reserve Bank of New York, vol. 15 (Winter):2032.

Rendelman, Richard, Charles Jones, and Henry Latanè. 1982. "Empirical Anomalies Based on Unexpected Earnings and the Importance of Risk Adjustments." Journal of Financial Economics, vol. 10, no. 3:269-87.

Rivera, J.M. 1991. "Prediction Performance of Earnings Forecasts: The Case of U.S. Multinationals." Journal of International Business Studies, vol. 22, no. 2:265-88.

Roll, Richard. 1978. "Ambiguity When Performance is Measured by the Securities Market Line." The Journal of Finance, vol. 33, no. 4:1051-69.

1992. "Industrial Structure and the Comparative Behavior of International Stock Market Indices." The Journal of Finance, vol. 47, no. 1 (March):3-37.

Ruland, W., S. Tung, and N.E. George. 1990. "Factors Associated with the Disclosure of Managers' Forecasts." Accounting Review, vol. 65, no. 3 (July):710-21. 
Sakakibara, Shigeki, Hidetoshi Yamaji, Hisaktsu Sakurai, Kengo Shiroshita, and Shimon Fukuda. 1988. The Japanese Stock Market: Pricing Systems and Accounting Information. New York: Preager Publishing.

Satoh, Hiromitsu. 1979. "Financial Reporting and the Stock Market: On the Information Effects of the Earnings Announcements." Kigyo-Kaikei (Business Accounting), vol. 31:60-79. (In Japanese)

Theil, Henri. 1966. Applied Economic Forecasting. Amsterdam, North-Holland; Chicago, Rand McNally.

Weinstein, Neil. 1980. "Unrealistic Optimism about Future Life Events." Journal of Personality and Social Psychology:806-20.

Wiggins, James. 1991. "The Earnings-Price and Standardized Unexpected Earnings Effects: One Anomaly or Two?" Journal of Financial Research, vol.14, no. 3:263-75.

Zielinski, R., and N. Holloway. 1991. Unequal Equities: Power and Risk in Japan's Stock Market. Tokyo and New York: Kodansha International.

Ziemba, W.T. 1991. "Japanese Security Regularities: Monthly, Turn-of-the-Month and Year, Holiday and Golden Week Effects." Japan and the World Economy, vol. 3, no. 2:119-46. 